\title{
Between Local Knowledge and National Politics: Debating Rationales for Jury Nullification
}

\author{
After Bushell's Case
}

\author{
Simon Stern
}

Sir John Vaughan's opinion in Bushell's Case' constitutes an important milestone in the history of jury nullification in Anglo-American law. In ruling that jurors may not be fined or imprisoned for returning a verdict that conflicts with the judge's assessment of the evidence, Vaughan made a formative contribution to our understanding of the jury's independence, and his opinion continues to be cited in discussions of this issue. ${ }^{2}$ Vaughan did not defend nullification: His opinion nowhere speaks of a juror's right to disregard the law or to find according to "conscience," a term that some

1. Vaughan 135, 124 Eng. Rep. 1006 (C.P. 1670). Other versions of the decision are reported at T. Jones 13, 84 Eng. Rep. 1123 (C.P. 1670), and 1 Freeman 2, 89 Eng. Rep. 2 (C.P. 1670). I do not use these redactions, however, because the reports of Jones and Freeman were not published until well into the following century, and thus were unavailable to most of the commentators discussed in this Note. See RICHARD FREEMAN, REPORTS OF CASES ARGUED AND ADJUDGED IN THE COURTS OF KING'S BENCH AND COMMON PLEAS, FROM 1670 TO 1706 (Thomas Dixon ed., London, Lintot 1742); THOMAS JONES, THE REPORTS OF SEVERAL SPECIAL CASES ADJUDGED IN THE COURTS OF KING's BENCH AND COMMON PlEAS (London, E. \& R. Nutt \& E. Gosling 1729). Vaughan's report was first published in 1677. See infra note 20.

2. See, e.g., United States v. Reynolds, 397 U.S. 14, 24 (1970) (citing Bushell's Case for the proposition that juries "perform ... an historic restraint on both executive and judicial power"); United States v. Schmitz, 525 F.2d 793, 794 (9th Cir. 1975) ("Bushel[l]'s case settled it that a judge is not permitted to force a jury to find a defendant guilty ....”); Claudio v. State, 585 A.2d 1278, 1303 n.65 (Del. 1991) ("Ever since Bushell's Case, the jury's independence from official reprisal has been maintained and courts have been precluded from inquiring into the jury's deliberative process."); People v. Douglas, 680 N.Y.S.2d 145, 148 (Sup. Ct. 1998) (stating that Bushell's Case "effectively insulated the jury's decisionmaking from court interference 'wherein they resolve both law and fact complicatedly, and not the fact by itself" (misquoting Bushell's Case, 124 Eng. Rep. at 1013)). 
contemporary commentators used as a code word for nullification. ${ }^{3}$ Insofar as Vaughan addressed the issue at all, he insisted that the jury must follow the judge's directions concerning the law. Nevertheless, Bushell's Case would prove to be a valuable resource for those who did advocate jury nullification. Vaughan relied in part on the observation that reasonable people may disagree about a witness's credibility or the reliability of the evidence; in such cases, he argued, the jurors should form their own views and should not be punished if these views differed from the judge's. Modern defenses of jury nullification that draw on Vaughan's opinion often rely on this strand of his argument. ${ }^{4}$ When Bushell's Case was first publicly debated in the early 1680 s, however, the journalists and pamphleteers who cited it focused on a different justification. Besides defending the right to form an independent view, Vaughan also reasoned that because jurors were chosen from the vicinage (the locality where the crime occurred), they might have personal knowledge about the facts of the case. As John Langbein has noted, this argument was completely implausible, since the English had abandoned the vicinage requirement for a countywide venire system in the sixteenth century. ${ }^{5}$ Nevertheless, Vaughan's latter justification played a crucial role in the process by which Bushell's Case came to stand for the principle that jurors have the right to nullify. By the end of the eighteenth century, the "personal knowledge" claim no longer seemed defensible; however, by that point, largely because of the debates of the 1680s, Bushell's Case had long been viewed as supporting the jury's right to find both law and fact-a right that Vaughan had never defended.

Previous discussions of Bushell's Case have underestimated its impact on the nullification debate. Langbein has argued that the 1670 ruling had

3. See Thomas ANDREW GREEN, Verdict ACCORDING To CONSCIENCE: PERSPECTIVES ON the English CRiminal Trial Jury 1200-1800, at 153-99 (1985) (discussing the use of "conscience" by advocates of jury nullification beginning in the mid-seventeenth century).

4. For articles that quote Vaughan's comments concerning physical and mental perception, see, for example, Paul Butler, Racially Based Jury Nullification: Black Power in the Criminal Justice System, 105 YALE L.J. 677, 702 (1995); David N. Dorfman \& Chris K. lijima, Fictions, Fault, and Forgiveness: Jury Nullification in a New Context, 28 U. MICH. J.L. REFORM 861, 870 n.36 (1995); Robert D. Rucker, The Right To Ignore the Law: Constitutional Entitlement Versus Judicial Interpretation, 33 VAL. U. L. REv. 449, 451 (1999); and Chaya Weinberg-Brodt, Note, Jury Nullification and Jury-Control Procedures, 65 N.Y.U. L. REV. 825, 830 n.28 (1990).

5. See John H. Langbein, The Criminal Trial Before the Lawyers, 45 U. CHI. L. REV. 263, 298 \& n.105 (1978) (arguing that "[t]he reason for [the] decision voiced in the opinion in Bushell's Case is dishonest nonsense" and that "[p]robably in the later fifteenth century, but certainly by the sixteenth, it had become expectable that jurors would be ignorant of the crimes that they tried," because of the shift from a jury of the locality to a countywide system). One scholar has argued that the Year Books at the end of the sixteenth century reveal a "'growing acquiescence in the practical conclusion that where juries came from made little difference, since personal cognizance rarely figured in their verdicts anyhow." Richard J. Ross, The Memorial Culture of Early Modern English Lawyers: Memory as Keyword, Shelter, and Identity, 15601640, 10 YaLE J.L. \& Human. 229, 264 n.119 (1998) (quoting Charles Gray, Domestic Venue 34 (1997) (unpublished manuscript)). Ross also cites a series of cases decided between 1538 and 1569 that reflect the shift to a countywide jury. $I d$. 
little immediate effect, because judges could still comment freely on the facts of a case, terminate the trial at any point prior to the jury's verdict, require the jury to redeliberate, and seek royal pardons for defendants whom the jury convicted against the judge's direction. ${ }^{6}$ These options, however, applied only to petit jury trials, not to grand jury proceedings, and it was in this latter context that Bushell's Case would first command public attention. Though Thomas Andrew Green has discussed two of the early responses to Bushell's Case, ${ }^{7}$ his discussion does not address their relation to the jury hearings that prompted them, or to the other books, pamphlets, and newspaper editorials that also contributed to the nullification debate. Barbara J. Shapiro has examined a number of the contributions to that debate and has addressed their political motivations, but her account focuses on the debate's role in the history of proof standards in English law. ${ }^{8}$

What has not been sufficiently explored, then, is the process by which Vaughan's defense of jury independence was translated into a defense of jury nullification in the early 1680s. Vaughan's comments on the distinction between fact and law suggest that nullification, though impermissible, is virtually impossible to prevent; however, the rhetorical battle over the meaning of Bushell's Case would turn nullification into a right. This battle shows how the interpretation of Bushell's Case was molded to suit a particular political agenda; it also shows how the reception of legal opinions may be influenced by the popular press. The licensing regulations that controlled the print marketplace until 1679 would have made it nearly impossible to engage in such widespread dissemination of views that served to undermine the Crown's power. Had those regulations remained in effect, commentary on Vaughan's opinion would probably have appeared over a period of decades, in discussions limited mainly to legal treatises, rather than erupting into a fast-paced public debate. ${ }^{9}$

\footnotetext{
6. See Langbein, supra note 5, at 284-300.

7. See GREEN, supra note 3, at 252-62.

8. See Barbara J. Shapiro, "Beyond Reasonable Doubt" and "Probable Cause": HISTORICAL PERSPECTIVES ON THE ANGLO-AMERICAN LAW OF EVIDENCE (1991).

9. Thus, for example, in what appears to be the only contemporary treatise devoted specifically to the jury, Giles Duncombe's Tryals per Pais, precisely the same account of Bushell's Case appears in the second edition, published in 1682, and the eighth edition, published in 1766. Duncombe's book says nothing about jury law-finding, but simply explains that "the Judge cannot fine the Jury, for going against their Evidence [in court], or Direction of the Court," and quotes Vaughan's arguments concerning the jurors' other possible sources of knowledge. Giles Duncombe, Tryals per PaIs, OR The Law of England CONCERNING JuRIES 444 (London, George Dawes 2d ed. 1682) (1665) [hereinafter DUnCOMBE, TrYaLS]; 1 GILES DUNCOMBE, TRIALS PER PAIS: OR, THE LAW OF ENGLAND CONCERNING JURIES 274 (London, H. Woodfall \& W. Strahan for T. Waller 8th ed. 1766) (1665). Imprints of the latter sort were not uncommon, see, e.g., infra notes 20, 105; the format indicates that Woodfall and Strahan were the printers, but that Waller owned the copyright. See M.A. Shaaber, The Meaning of the Imprint in Early Printed Books, 24 LIBRARY (4th ser.) 120, 127-28 (1944). The lack of any such distinction
} 
Although arguments defending jury nullification had been raised in print before $1680,{ }^{10}$ the debate of the 1680 s constituted the first open, extended discussion of the issue in England, and its repercussions continue into the present. In United States $v$. Thomas, ${ }^{11}$ a recent Second Circuit decision, the court ruled that "a juror who intends to nullify the applicable law is ... subject to dismissal." "12 Some have defended this holding, arguing that American courts have never tolerated nullification, ${ }^{13}$ while others have criticized Thomas as a historically unprecedented infringement of the jury's rights. ${ }^{14}$ This Note does not attempt to resolve that debate, although evidence suggests that some American courts in the eighteenth and nineteenth centuries permitted jury law-finding to an extent that made nullification virtually inevitable. ${ }^{15}$ Regardless of whether that evidence constitutes endorsement of nullification, however, Thomas and Bushell's Case are strikingly similar in their conclusions about the court's ability to respond to jurors who nullify. The Thomas court observed that the need to keep jury deliberations secret makes it nearly impossible for judges to prevent nullification. ${ }^{16}$ Indeed, the court set a very high evidentiary standard

in the imprint, however, does not necessarily indicate that the printer was the copyright holder. See infra note 103.

10. See GREEN, supra note 3, at 153-207 (discussing the pro-nullification pamphlets of John Lilburne and other Levellers, published in 1657).

11. 116 F.3d 606 (2d Cir. 1997).

12. Id. at 614 .

13. See, e.g., David A. Pepper, Nullifying History: Modern-Day Misuse of the Right To Decide the Law, 50 CASE W. RES. L. REV. 599, 609 (2000) (arguing that in the eighteenth and nineteenth centuries, "the right to decide the law swept narrowly, placing a clear duty on juries to follow the law as they saw it, rather than reject the law as pro-nullification scholars would have them do").

14. See, e.g., Nancy S. Marder, The Myth of the Nullifying Jury, 93 Nw. U. L. REV. 877, 87879 (1999) (arguing that Thomas reflects "judicial ... efforts to weaken the jury"); Ran Zev Schijanovich, Note, The Second Circuit's Attack on Jury Nullification in United States v. Thomas: In Disregard of the Law and the Evidence, 20 CARDOZO L. REV. 1275, 1277 (1999) (arguing that Thomas represents a "departure from federal court precedent and the spirit of the jury's role in America from colonial times to the present").

15. See, e.g., Georgia v. Brailsford, 3 U.S. (3 Dall.) 1, 4 (1794) (instructing the jury that it had "a right ... to determine the law as well as the fact in controversy"); United States v. Hutchings, 26 F. Cas. 440, 442 (C.C.D. Va. 1817) (No. 15,429) ("[T] he jury in a capital case [are] judges, as well of the law as the fact . ..."); United States v. Hodges, 26 F. Cas. 332, 334 (C.C.D. Md. 1815) (No. 15,374) ("The jury are not bound to conform to [the judge's] opinion, because they have a right in all criminal cases to decide on the law and the facts."); United States $v$. Hoxie, 26 F. Cas. 397, 402 (C.C.D. Vt. 1808) (No. 15,407) ("[A] jury has a right to take upon itself the decision of both law and fact."); see also John D. Gordan III, Juries as Judges of the Law: The American Experience, 108 LAW Q. REV. 272 (1992) (collecting cases involving lawfinding by juries); Mark DeWolfe Howe, Juries as Judges of Criminal Law, 52 HARV. L. REV. 582 (1939) (same); Stanton D. Krauss, An Inquiry into the Right of Criminal Juries To Determine the Law in Colonial America, 89 J. CRIM. L. \& CRIMINOLOGY 111 (1998) (same).

16. Thomas, 116 F.3d at 618 " As a general rule, no one-including the judge presiding at a trial-has a 'right to know' how a jury, or any individual juror, has deliberated or how a decision was reached by a jury or juror."); $i d$. at 621 ("Where . . . a presiding judge receives reports that a deliberating juror is intent on defying the court's instructions on the law, the judge may well have no means of investigating the allegation without unduly breaching the secrecy of deliberations."). 
for judges who would dismiss nullifying jurors ${ }^{17}$-a standard that had not been met by the district court, with the result that the defendant was entitled to a new trial. ${ }^{18}$ Similarly, Vaughan concluded that "legally it will be very hard to quit a jury that finds against the law." ${ }^{19}$ Thomas and Bushell's Case reach nearly identical conclusions; the most salient difference is that Vaughan addressed the topic of nullification only implicitly, and his ambiguity on that subject made it possible for commentators to reshape his opinion during the ensuing debate.

That debate arose because of a series of government-sponsored prosecutions in 1680-1681 of Whig dissidents accused of seditious libel and treason. King Charles II and his Tory supporters were initially successful in prosecuting their political opponents, but several of these cases were halted when grand juries dominated by Whigs returned findings of ignoramus ("we know nothing of it"), which indicated that the jurors saw no basis for pursuing the charges. In such cases, the judges had no means of circumventing the jury; the prosecution could bring the case again before another grand jury, but that effort seemed futile when the same Whigs controlled the venire. Political commentators seeking to justify the jurors' behavior found the perfect answer in Bushell's Case, published in 1677 in Vaughan's Reports. ${ }^{20}$ These writers' efforts were greatly assisted by the lapse in 1679 of the statute providing for government regulation of the press. Indeed, the lapse of the licensing regulations was the very reason for the flood of publications that the government was then attempting to curb by prosecuting the printers for seditious libel. Thus, Bushell's Case provoked heated debate over jurors' rights at a time when booksellers ${ }^{21}$ were not only enjoying a newfound liberty to encourage political controversy in general, but were also personally concerned about the outcome of this particular debate. Vaughan's opinion reached a print marketplace that was ideally positioned to exploit the case.

This Note analyzes the process by which the "personal knowledge" claim was taken up in the 1680 s and was ultimately rejected at the end of the following century. Part I reviews Bushell's Case itself in order to clarify

17. Id. at 621-22 ("[W]e must hold that if the record evidence discloses any possibility that the request to discharge la jurorl stems from the juror's view of the sufficiency of the government's evidence, the court must deny the request." (quoting United States v. Brown, 823 F.2d 591, 596 (D.C. Cir. 1987)) (second alteration in original)).

18. Id. at 625 .

19. Bushell's Case, 124 Eng. Rep. 1006, 1013 (C.P. 1670).

20. THE REPORTS AND ARGUMENTS OF THAT LEARNED Judge Sir John Vaughan KT. late ChIEF Justice of His MAJesties Court of COMMON Pleas 135 (London, Thomas Roycroft for Richard Marriott 1677).

21. I use the term "bookseller" here in its eighteenth-century sense, to refer to members of the book trade who combined what today would be the separate functions of publishing, printing, and retailing books. For further discussion, see Michael Treadwell, London Trade Publishers 1675-1750, 4 LIBRARY (6th ser.) 99, 99-100 (1982). 
the different bases of Vaughan's argument. Part II examines the historical and political context in which the nullification debate occurred. The terms "Whig" and "Tory" first came into popular usage at the end of the 1670s, at a time when the Whigs in the House of Commons were struggling with the Crown's Tory affiliates in the House of Lords over the monarch's authority and the power to control the royal succession. These years witnessed the Exclusion Crisis (1679-1681), so named because the Whigs were attempting to pass legislation that would prevent Catholics from occupying the throne; the legislation was targeted specifically at Charles's brother, James, Duke of York. ${ }^{22}$ During roughly the same period (16781684), England was reacting to threats of a "Popish Plot" to take over the government. ${ }^{23}$ These conflicts provoked a nationwide crisis and generated a huge amount of print that the government attempted to suppress by prosecuting the more outspoken booksellers for seditious libel.

Part III discusses these trials and the responses they provoked. During the first months of 1680, the government launched several successful prosecutions against Whig booksellers, most notably Benjamin Harris, who had contributed energetically to the stream of pamphlets offering dire warnings about the Popish Plot and the dangers of allowing James to succeed to the throne. These prosecutions led to the first efforts to introduce Bushell's Case to the public of potential jurors in order to justify jury independence. Another successful prosecution followed in July, but as the year wore on, juries grew reluctant to follow the government's lead and opted instead to block the attacks with ignoramus bills. The Whig resistance to government control of the press, and of public opinion, began to assert itself.

Part IV turns to the loudly contested treason trials of 1681 , in which the government prosecuted several Whig agitators who had sought to prevent James's succession and who had allegedly conspired to kidnap the King himself. ${ }^{24}$ Among the targets of these prosecutions were the Earl of Shaftesbury (the leader of the Whig party) and two of his associates, Stephen Colledge and John Rouse. The Tories ultimately prevailed in their effort to facilitate James's succession and to extract guilty verdicts for Colledge and Rouse, ${ }^{25}$ but each of these three prosecutions generated an

22. See J.R. JONES, THE FIRST WHIGS: THE POLITICS OF THE EXCLUSION CRISIS, 1678-1683 (1961); MARK KNIGHTS, POLITICS AND OPINION IN CRISIS, 1678-81 (1994).

23. See John KenYon, The POPISh Plot (1972).

24. For a discussion of this later phase of the Popish Plot, see sources cited supra note 22. See also PhILlip HaRTH, PEN fOR a PARTY: DRyden's TORY PROPAGANDA IN ITs CONTEXTS (1993) (discussing the treason trials and the political propaganda surrounding them); MELINDA S. ZOOK, RADICAL WhIGS AND CONSPIRATORIAL POLITICS IN LATE STUART ENGLAND (1999) (discussing the development of Whig ideology during and after the treason trials).

- 25. Rouse was hanged in 1683 after being implicated in the Rye House Plot, an alleged Whig conspiracy to kill both Charles and James. See ZooK, supra note 24, at 87-113, 199. 
ignoramus bill along the way. As a result, they effectually routinized a series of defenses for jury nullification. This Part focuses on the trial of Colledge, whose exoneration by a London grand jury provoked an especially vituperative response from the Tories, including a long string of screeds in the Observator in Dialogue, the newspaper of the Tory journalist and government censor Roger L'Estrange. ${ }^{26}$ His editorials, in turn, generated further defenses of nullification from the Whigs. The controversy about Colledge's case epitomizes a process that became familiar as the treason trials continued. The Tory criticisms and Whig defenses of the ignoramus bills set into circulation a whole kit of arguments concerning jurors' rights-and the debate was significant not only because of the claims the Tories criticized, but also because of the claims they conceded.

Part $\mathrm{V}$ analyzes the importation of these late seventeenth-century arguments to the American colonies in the eighteenth century. Several Whig defenses of jury nullification were reprinted in the American colonies, and these arguments were repeated during the debates over the ratification of the Constitution. In the course of the eighteenth century, however, the English courts had become hostile to the idea that jurors might base their deliberations on personal knowledge that had never been made public in court. This change was also reflected in the American courts, and after the turn of the eighteenth century, the "personal knowledge" argument was hardly raised at all, except when it was cited in order to be rejected. American courts, however, continued well into the nineteenth century to uphold the jury's right to find law. ${ }^{27}$ This pattern suggests that claims about the jurors' personal knowledge were useful in cultivating the defense of jury independence so that when they finally became untenable, Vaughan's other argument-concerning the juror's obligation to render an independent judgment - was sturdy enough to stand on its own. The debates of the early 1680 s show that just one decade after Vaughan handed down his opinion, polemicists had redacted it into a set of arguments that would crucially influence the future of the argument over jury nullification.

Just as Vaughan must have been aware that a petit jury could not be expected to have any personal knowledge about the case it was hearing, the Whig polemicists who recited Vaughan's arguments must have known that these claims made even less sense when applied to the grand jury, which was subject to no vicinage requirement of any sort. ${ }^{28}$ The Whigs may have

26. For a discussion of the history and publication of this newspaper, see Thomas C. Faulkner, The Publishing History of Sir Roger L'Estrange's Observator, 73 PAPERS BIBLIOGRAPHICAL SOC'Y AM. 89 (1979).

27. See supra note 15.

28. See, e.g., I William HOldSWORTH, A History OF ENGlish LAW 322 (7th ed. 1956) (stating that in the late fourteenth century, "the method of the selection of the grand jury changed," and that jurors were thereafter chosen "from the body of the county" (footnote omitted)). J.M. Beattie notes that at the end of the seventeenth century, the London grand jury 
reasoned that what worked for the petit jury was worth positing for the grand jury as well, but this does not explain why they reached so quickly for the unpersuasive "personal knowledge" argument when they might simply have turned to Vaughan's comments about individual perception. The Conclusion examines the functions that this argument served.

\section{VAUGHAN'S ARGUMENTS IN BUSHELL'S CASE}

Whatever he thought about the "personal knowledge" claim, Vaughan probably never imagined that it would come to provide a basic rationale for the jury's independence. That this aspect of his decision could be made to serve the Whigs' ends was a historical fluke. Bushell's Case arose out of an earlier case involving the prosecution of William Penn and William Mead for preaching to other Quakers in public. ${ }^{29}$ Vaughan's opinion thus protected the conduct of a jury sympathetic to the rights of religious dissenters, but his arguments would be adapted for the needs of a large and vocal political faction that saw itself beleaguered by a pattern of hostile prosecutions.

As a member of Parliament in the late 1660s, Vaughan had supported an unsuccessful bill forbidding judges to fine or punish jurors, ${ }^{30}$ and shortly after he was appointed to the Court of Common Pleas, he had an opportunity to rule on the issue. Bushell's Case arose when four jurors refused to convict. Penn and Mead of seditious preaching before an unlawful assembly. ${ }^{31}$ The Quakers, frequent targets of religious persecution under the Stuarts, had emphasized the jury's obligation to render a verdict "according to conscience," and when Penn and Mead were tried in 1670, they argued for acquittal based on freedom of conscience. Even after being locked up without food or drink, four members of the jury refused to convict; they found Penn guilty of "speaking in Gracechurch Street," ${ }^{32}$ but not to an unlawful assembly, and they found Mead not guilty. When the trial judge made them redeliberate, the jury returned a verdict of not guilty

included "seventeen men ... chosen from the twenty-six City wards . ... For the most part they were drawn from the upper ranks of the ... rate-paying population" and "were also widely experienced in other aspects of the government of the City." J.M. BEATTIE, POLICING AND PUNISHMENT IN LONDON, 1660-1750, at 51-52 (2001); see also SHAPIRO, supra note 8, at 276 n.11 (surveying arguments concerning the composition and conduct of grand juries during this period).

29. Bushell's Case, 124 Eng. Rep. 1006, 1006 (C.P. 1670).

30. See SHAPIRO, supra note 8, at 55, $281 \mathrm{n} .34$ (stating that Vaughan " appears to have been the sole speaker on the bill's second reading" (citing JOHN MILWARD, THE DIARY OF JOHN MLLWARD, ESQ., MEMBER OF PARLIAMENT FOR DERBYSHIRE, SEPTEMBER, 1666 TO MAY, 1668, at 190-91 (Caroline Robbins ed., Cambridge Univ. Press 1938))).

31. This paragraph draws on the accounts in GREEN, supra note 3, at 221-36, and John A. Phillips \& Thomas C. Thompson, Judges v. Jurors in Later Stuart England: The Penn/Mead Trial and Bushell's Case, 4 LAW \& INEQ. 189, 194-215 (1986).

32. Green, supra note 3 , at 225. 
for both defendants. Although the judge was forced to accept this verdict, he charged all of the jurors for returning a verdict contrary to the evidence and contrary to his instructions. They were fined forty marks ${ }^{33}$ each and were sent to Newgate Prison until they paid. Edward Bushell and three others refused to pay the fine and remained imprisoned until Vaughan ruled on their case.

Vaughan emphasized the jury's independence throughout his opinion. His central concerns involved the legitimacy of the jury system, the problem that law and fact are not always distinct, and the importance of crediting jurors' perceptions of the evidence. First, Vaughan argued that unless the jury can act independently of the judge, it cannot command public support:

[I]f the Judge having heard the evidence ... shall tell the jury ... the law is for the plaintiff, or for the defendant, and you are under the pain of fine and imprisonment to find accordingly, ... every man sees that the jury is but a troublesome delay ... and therefore the tryals by them may be better abolish'd than continued; which were a strange new-found conclusion, after a tryal so celebrated for many hundreds of years. ${ }^{34}$

This argument speaks to the legitimacy-and indeed the very point-of the jury's decisions: If these assessments are to be trustworthy, they cannot simply be dictated by the judge. This explanation thus speaks to the public's faith in, and commitment to, the jury system as an institution. Vaughan did not draw out this implication, but later commentators noted that if judges could punish jurors for returning disobedient verdicts, few would be eager to serve on juries in the first place. ${ }^{35}$

Second, in discussing the jurors' power to form their own conclusions, Vaughan offered a cryptic discussion that the Whigs would soon appropriate for their own ends, producing an interpretation that Vaughan almost certainly would have challenged had he anticipated it. He distinguished between special verdicts and general verdicts, noting that the latter category typically combines issues of law and fact: "[U]pon all general issues; ... though it be matter of law whether the defendant be a

33. A mark was worth two-thirds of a pound. See NICHOLAS MAYHEw, STERLING: THE RISE AND FALL OF A CURRENCY 2 (1999). Beattic has examined the composition of London juries in the 1690s; if the figures in that study apply to the 1670 s, forty marks probably represented less than ten percent of most jurors' total wealth (which in many cases was above £300), but it represented at least half of the annual rental income from the real estate owned by all except the wealthiest ten percent of jurors. See J.M. Beattie, London Juries in the 1690s, in TWELVE GOOD MEN AND TRUE: THE CRIMINAL TRIAL JURY IN ENGLAND, 1200-1800, at 214, 232-33, 241 tbl.8.7 (J.S. Cockburn \& Thomas A. Green eds., 1988).

34. Bushell's Case, 124 Eng. Rep. at 1010.

35. See, e.g., infra text accompanying note 139 . 
trespasser, a debtor, disseisor, or disturber[,] ... [the jurors] resolve both law and fact complicately," because they must "determine the law in all matters where issue is joyn'd." ${ }^{36}$ This statement does not convey what Green calls Vaughan's "absolute conviction that jurors were judges only of fact and not of law." ${ }^{77}$ Elsewhere in his opinion, Vaughan underscored this distinction more emphatically; thus, for example, he insisted that "no evidence was, or can be given to a jury [to decide] what is law," 38 and he remarked that if the judge, prior to hearing the verdict, were to inquire about the jury's finding of fact, a directed verdict would be appropriate. ${ }^{39}$ Vaughan's failure to reiterate that point in his discussion of general verdicts would prove crucial, since the Whig polemicists who happened upon this passage would adopt, as a kind of mantra, the claim that juries may find both law and fact, provided that the two are so intermixed as to be inseparable. This proviso, of course, is almost infinitely flexible; in effect, it justifies any act of jury law-finding, because any jury intent on nullifying can find a way to make the case hinge on the application of law to fact. Nullification advocates quoting Vaughan's language would, in fact, soon argue that "general issues" so thoroughly dominate the jury's attention as to make jury law-finding an everyday matter. ${ }^{40}$

Third, and most crucially for the nullification debate, Vaughan was not entirely consistent about the jurors' basis for taking an independent view. Early in the opinion, Vaughan implied that no juror's conclusion can be presumed to be "against the evidence," because people disagree all the time: "I would know whether any thing be more common, than for two men students, barristers, or Judges, to deduce contrary and opposite conclusions out of the same case in law? And is there any difference that two men should inferr distinct conclusion from the same testimony ... ?"41 Several pages later, Vaughan returned to the point: "A man cannot see by anothers eye, nor hear by anothers ear, no more can a man conclude or

36. Bushell's Case, 124 Eng. Rep. at 1013.

37. GREEN, supra note 3 , at 239.

38. Bushell's Case, 124 Eng. Rep. at 1010.

39. In such a case, Vaughan explained, "the Judge [may] declare, the matter of fact being by you so found to be, the law is for the plaintiff, and you are to find accordingly for him." Id. Vaughan added:

If notwithstanding [the jury] find for the defendant, this may be thought a finding in matter of law against the direction of the Court; for in that case the jury first declare the fact, as it is found by themselves, to which fact the Judge declares how the law is Id. consequent.

40. See, e.g., infra text accompanying note 169.

41. Bushell's Casc, 124 Eng. Rep. at 1009. Quite apart from Vaughan's remarks about personal knowledge, this argument also provides the basis for entrusting the jury with determining the credibility and reliability of the evidence presented to it. See, e.g., George Fisher, The Jury's Rise as Lie Detector, 107 YALE L.J. 575 (1997). 
inferr the thing to be resolv'd by anothers understanding or reasoning." ${ }^{42}$ It might appear, then, that Vaughan simply meant to protect the jurors' personal assessment of the evidence before them.

In one significant and extended passage, however, Vaughan credited the jurors not simply with a personal view of the evidence, but with personal knowledge about the case. Purporting to believe that the obsolete vicinage requirement remained an important part of the venire system, he suggested that those from the locality had better information than the judge:

Being return'd of the vicinage, whence the cause of action ariseth, the law supposeth them thence to have sufficient knowledge to try the matter... though no evidence were given on either side in Court, but to this evidence the Judge is a stranger. . . They may have evidence from their own personal knowledge ... that what is depos'd in Court, is absolutely false; but to this the Judge is a stranger. ${ }^{43}$

Vaughan applied the same logic in discussing the requirement for hundredors, members of an even smaller local unit than the vicinage. ${ }^{44}$ Technically, two hundredors were required to sit on juries, ${ }^{45}$ but the requirement was not strictly enforced at this time and was eliminated a few decades later. ${ }^{46}$ Nevertheless, Vaughan treated this provision as an important demand for local knowledge: "To what end must hundredors be of the jury, whom the law supposeth to have nearer knowledge of the fact than those of the vicinage in general?" 47 Continuing this thought two paragraphs later, he found it "absurd [that] a jury should be fined by the Judge for going against their evidence" when "the jury find" the facts "upon their own knowledge." 48

42. Bushell's Case, 124 Eng. Rep. at 1013.

43. Id. at 1012 .

44. Sir Thomas Smith, writing in the mid-sixteenth century, defined a "hundred" as a "division[]" of a county (or shire), explaining that "the shires be divided some into $x$. xii. xiii. xvi. xx. or xxx. hundreds, more or lesse." ThOMAS SMITH, DE REPUBLICA ANGLORUM 100 (Mary Dewar ed., Cambridge Univ. Press 1982) (1583)

45. See An Act for Returning of Sufficient Jurors, and for Better Expedition of Trials, 27 Eliz., c. $6, \S 5(1585)$ (reducing the requisite number of hundredors from six to two in trials of personal actions).

46. The requirement was eliminated for civil cases in 1705. See An Act for the Amendment of the Law, and the Better Advancement of Justice, 4 Ann., c. 16, § 6 (1705). James C. Oldham notes that throughout the seventeenth century, "there were some limitations on challenges for default of hundredors. Juries in treason and felony trials were to be drawn from the shire where the acts were laid, but no challenge was 'to be had for the Hundred." James C. Oldham, The Origins of the Special Jury, 50 U. CHI. L. REV. 137, 165 n.149 (1983) (quoting FERDINANDO PuLTON, DE PACE REgIS ET REGNI 242a (London, 1610)).

47. Bushell's Case, 124 Eng. Rep. at 1012.

48. Id. at 1013 . 
Green finds it "unclear just how significant these arguments were for Vaughan," 49 and, indeed, Vaughan might have rested his argument entirely on the claim that jurors' perceptions, however formed, deserve that minimal degree of respect that forbids a skeptical judge from imposing any punishment. On one hand, it might seem that Vaughan's purpose was more rhetorical than substantive, and that he multiplied examples simply to emphasize the futility of such punctilious requirements if the jury is merely a pawn of the judge. At the same time, these remarks about personal knowledge-a justification that Vaughan himself must have known to be outdated - are tightly interwoven with his discussion of the idiosyncratic nature of individual perception. His observation about the impossibility of using another's eyes or ears appears in the paragraph that separates his discussion of the hundredors from his remarks about the "absurd[ity]" of punishing jurors when the judge is unaware of the facts. ${ }^{50}$ In fact, these are the only lines in which Vaughan clearly credited the jurors with anything more than general knowledge about the local background: To have "sufficient knowledge to try the matter" or to recognize testimony as "false" may not require any awareness of the particular events under dispute, but to have superior "knowledge of the fact" is presumably to have some familiarity with those events. ${ }^{51}$ Notably, Vaughan ascribed that heightened level of knowledge not to the "vicinage in general" but to the hundredors, whose presence on the petit jury had declined significantly in the sixteenth century ${ }^{52}$ and who probably lacked any particular expertise in any case. ${ }^{53}$

Conceptually, of course, the two strands of Vaughan's argument are separable. What is noteworthy, however, is that when he alternated between discussing the jurors' independent access to information and their use of their own sensory organs, Vaughan used both arguments to justify the claim that opened this section of his opinion-namely, that "the Judge, quà

49. GREEN, supra note 3 , at 245.

50. See supra text accompanying notes $47-48$.

51. See supra text accompanying notes 43,47 .

52. See supra text accompanying note 45 .

53. Professor Oldham notes:

By the mid-sixteenth century, it was fanciful to view the hundredor requirement as likely to produce jurymen who were "experts" in the sense of being especially knowledgeable about the facts in dispute. Arguably the requirement never had this effect, but was merely a transitional device preserving the appearance of the old jury of witnesses while the jury assumed its new role of deciding the facts based on evidence presented in court.

Oldham, supra note 46 , at 167 . He adds that "[t]he idea that by being neighbors to the event jurors would know the facts was tenacious, finding repeated expression well into the eighteenth century." Id. at 167 n.156. Phillips and Thompson's account ascribes more credit to this part of Vaughan's analysis. See Phillips \& Thompson, supra note 31, at 221 ("However anachronistic the idea of a juror's private knowledge of a case might have been by 1670 , it constituted accepted legal theory at the time and continued to be a part of the law well into the next century."). 
Judge, ... can never know what evidence the jury have, and consequently he cannot know the matter of fact, nor punish the jury for going against their evidence." ${ }^{54}$ For this reason, despite the various assertions in Bushell's Case that jurors are restricted to findings of fact and must adhere to the judge's instructions concerning the law, Vaughan concluded that judges can rarely, if ever, be certain that jurors are nullifying.

If Vaughan saw nullification as an impermissible act that judges were not permitted to prevent, however, the Whigs who availed themselves of his opinion viewed Bushell's Case as a defense of nullification. Moreover, they often applied its holding to the grand jury, which was drawn from the entire county and included no vicinage requirement of any sort. The Tories would challenge them for equating the grand and petit juries, but because the Whig polemicists overstated their case in this manner, they seem to have prevailed with the seemingly milder, but equally dubious, defense of nullification by petit juries. If the Whigs had never sought to defend grand jury nullification in the first place, the Tories might have had the rhetorical leverage to oppose the "personal knowledge" claim more generally, and thus to attack the suggestion that Bushell's Case created a right to nullify. By overreaching, the Whigs apparently forestalled the perfectly reasonable objection that petit jurors had no more access to local information than did grand jurors.

\section{RESTORATION POLITICS AND PRINT}

Bushell's Case would probably have received little attention during the later seventeenth century if Vaughan's Reports had not been published at the outset of a particularly volatile period in English political history. Taken together, the Popish Plot and the Exclusion Crisis, accompanied by the birth of modern party politics, produced the fodder for a series of extended national conflicts, and the lapse of the Licensing Act provided the means to keep them before the public eye. These controversies, fueled in large part by anti-Catholic sentiment, were both a symptom and a cause of the political instability that would ultimately lead to the Glorious Revolution of 1688-1689, in which James was deposed in favor of his daughter Mary and her husband, William of Orange, both of whom were Protestant. When Titus Oates, an expelled Catholic seminarian, claimed in 1678 to have discovered evidence of a "Popish Plot" to burn London, assassinate the King, and take control of the government, he initiated six years of hysteria that ended only with his own arrest and imprisonment in $1684 .{ }^{55}$ The resulting intensification of anti-Catholic hostility helped bring about a two-

54. Bushell's Case, 124 Eng. Rep. 1006, 1012 (C.P. 1670).

55. For a discussion of these events, see KENYON, supra note 23. 
year legislative struggle concerning James's succession to the throne; shortly after the crisis began in 1679 , the so-called exclusionists, led by the Earl of Shaftesbury, became identified as the Whig party, and their opponents, who supported Charles's court and the government, were identified as Tories. The derivations of these names give some indication of the level to which political debate had descended: "Whig" was an insult applied to horse thieves, while "Tory" was an Irish term for Catholic outlaws.

The elimination of preprint censorship was one of the crucial conditions for the continuation of political controversy and the debate over the meaning of Bushell's Case. Prior to 1679, publishing was regulated by the Licensing Act, ${ }^{56}$ first passed in 1662 and renewed periodically thereafter. That statute, a latter-day version of the press controls maintained by the English Crown since the $1550 \mathrm{~s},{ }^{57}$ had imposed limits on the number of presses in London and had forbidden the publication of any material without prior approval by the government-appointed licenser. ${ }^{58}$ Because of its sunset provision, the Licensing Act was up for renewal in the spring of 1679, at the same time that the exclusionists in the House of Commons were beginning to organize against James's succession. ${ }^{59}$ Charles

56. An Act for Preventing Abuses in Printing Seditious, Treasonable, and Unlicensed Books and Pamphlets, and for Regulating of Printing and Printing-Presses, 13 \& 14 Car. 2, c. 33 (1662). The Act remained in effect from 1662 to 1679 and from 1685 to 1695 . See id. (effective 16621664); An Act for Continuance of a Former for Regulating the Press, 16 Car. 2, c. 8 (1664) (effective 1664-1665); An Act for Continuance of a Former for Regulating the Press, 16 \& 17 Car. 2, c. 7 (1665) (effective 1665); An Act for Continuance of a Former Act for Regulating the Press, 17 Car. 2, c. 4 (1665) (effective 1665-1679); An Act for Reviving and Continuance of Several Acts of Parliament Therein Mentioned, 1 Jam. 2, c. 17, § 15 (1685) (effective 1685-1693); An Act for Reviving, Continuing, and Explaining Several Laws Therein Mentioned, Which Are Expired and Near Expiring, 4 \& 5 W. \& M., c. 24, \& 14 (1692) (effective 1692-1695); see also LOIS G. SCHWOERER, THE INGENIOUS Mr. HeNry CARE, RESTORATION PUbliCist (2001) (discussing the relation between Restoration politics and the regulation of print); Raymond Astbury, The Renewal of the Licensing Act in 1693 and Its Lapse in 1695, 33 LIBRARY (5th ser.) 296 (1978) (discussing opposition to the Licensing Act); Timothy Crist, Government Control of the Press After the Expiration of the Printing Act in 1679, 5 PUBLISHING HIST. 49 (1979) (discussing government prosecution of booksellers in 1679-1680); Philip Hamburger, The Development of the Law of Seditious Libel and the Control of the Press, 37 STAN. L. REV. 661, $682-90$ (1985) (discussing the results of the lapse of the Licensing Act between 1679 and 1685).

57. See Cyprian Blagden, The Stationers' Company 20-21 (1960) (describing the terms of the charter granted to the stationers' guild in 1557).

58. See An Act for Preventing Abuses in Printing Seditious, Treasonable, and Unlicensed Books and Pamphlets, and for Regulating of Printing and Printing-Presses, 13 \& 14 Car. 2, c. 33 (1662).

59. The Whigs extended the debate over licensing in Commons in order to introduce evidence that the system had fostered the publication of pro-Catholic books while preventing the publication of Protestant works. See 9 H.C. JOUR. 600 (1679); Hamburger, supra note 56, at 683. Hamburger notes that the Whigs may have hoped that the delay would provide additional time for passage of the Exclusion Bill, and he suggests that the Licensing Act's lapse was an inadvertent result of these other maneuvers. See Hamburger, supra note 56, at 683 (finding "no evidence that any members of Parliament wished to abolish censorship altogether"). There was some active opposition, however, to the Act's renewal. See PHILOPATRIS, A JUST VindiCATION OF LEARNING 3-4 (London, 1679) (noting that "the late Act which laid that severe restraint upon Printing, is ... 
forestalled their efforts by adjourning Parliament prematurely, and, as a consequence, the government lost its most effective means of censorship, resulting in what one historian describes as an "explosion in the production of pamphlets, broadsheets, and periodicals such as had not been seen since the heady days of the 1640s." ${ }^{60}$ Thus, in solving one political problem, Charles created another: By lifting the regulations associated with more than a century of prepublication censorship, he unleashed the restraints that might otherwise have controlled political debate in the print marketplace, and the government was left with the comparatively ineffectual alternative of attempting to prosecute the authors and booksellers for books that had already begun to circulate. ${ }^{61}$

\section{THE Seditious Libel Prosecutions of 1679-1680}

The debate over Bushell's Case began as the result of a series of concerted attacks by Charles's government against the Whig political press in 1679-1680. The first effort to interpret and publicize Vaughan's opinion in the pamphlet literature was John Hawles's The English-Mans Right, ${ }^{62}$ published several months after the successful prosecution of the Whig bookseller Benjamin Harris in February 1680. Hawles, a lawyer who would later become Solicitor General under William and Mary, focused specifically on the petit jury and devoted nearly twenty pages to Bushell's Case. Although he mentioned the argument that jurors are entitled to form their own opinions, he gave much more space to the "personal knowledge" argument; his care in reviewing it, at this early date, probably helped it to achieve the popularity it would gain a year later, when other commentators joined the debate. The prosecutions continued through the end of 1680 , but

near Expiring," and calling "Liberty of the Press" the surest means of combating "Popish Villanies" (emphasis altered)); see also SCHwOERER, supra note 56, at 16 (arguing that the lapse "was not the result of mindless inattentiveness" and that "interest in press control was widespread in the spring of 1679"). There is some uncertainty about when the Licensing Act lapsed. See KNIGHTS, supra note 22, at 156 n.15 (citing conflicting authorities giving either March 13 or June 10 as the date of expiration).

60. Treadwell, supra note 21, at 129; see also O.W. Furley, The Whig Exclusionists: Pamphlet Literature in the Exclusion Campaign, 1679-81, 13 CAMBRIDGE HIST. J. 19 (1957) (discussing the outpouring of Whig political writing after the lapse of the Licensing Act in 1679); J. Walker, The Censorship of the Press During the Reign of Charles II, 35 HISTORY 219 (1950) (discussing government regulation of the press between 1662 and 1679).

61. The Licensing Act was restored in 1685, when James took the throne. See An Act for Reviving and Continuance of Several Acts of Parliament Therein Mentioned, 1 Jam. 2, c. 17, $\$ 15$ (1685).

62. JOHN HAWLES, THE ENGLISH-MANS RIGHT (London, Richard Janeway 1680); see also GREEN, supra note 3, at 252 (noting that Hawles's pamphlet was inspired by Harris's prosecution). Green, however, places in this category not only the writings of John Hawles, but also Henry Care's pamphlet, English Liberties, which Green also dates to 1680. Id. at 252 n.207. Care's pamphlet, which bears no date on its title page, was actually published in 1682 . For a discussion of this pamphlet and its dating, see infra note 160 . 
after another successful case in July 1680, the grand juries became less cooperative. In September, three prosecutions were halted by findings of ignoramus, and the following month, Hawles published a pamphlet, The Grand-Jury-Man's Oath and Office Explained, which discussed the rights of grand jurors. ${ }^{63}$ There, rather than pursuing the "personal knowledge" argument, Hawles emphasized the grand jurors' obligation to scrutinize the evidence carefully rather than merely rubber-stamping it. Significantly, even while repeating the point that judges may not fine the jurors, Hawles also acknowledged the jury's obligation to follow the judge's directions on matters of law. ${ }^{64}$ It appears that the only other contribution to the nullification debate at this stage was a leaflet, printed by Benjamin Harris, that posed a series of rhetorical questions that functioned as a kind of checklist of concerns that nullifying jurors might invoke. This leaflet adapted several of Hawles's arguments and indicates the popularity that they would acquire as the debate gained steam. ${ }^{65}$

\section{A. Harris's Trial and Hawles's Celebration of Bushell's Case}

The government effort to control the Whig press began in the autumn of 1679 , when three booksellers were arrested and jailed to await trial early the following year. ${ }^{66}$ The trial of Benjamin Harris set the stage for the jury nullification arguments that would provoke extensive debate during the later phases of the Popish Plot. On February 5, in "the first political trial of 1680," ${ }^{67}$ Harris was tried before Lord Chief Justice Scroggs for publishing

63. JOHN HAWLeS, THE GRAND-JURY-MAN's OATH AND OFFICE EXPLAINED (London, Langley Curtis 1680).

64. See infra note 110.

65. See infra text accompanying notes 112-115.

66. For a useful account of this period, see Alfred F. Havighurst, The Judiciary and Politics in the Reign of Charles II, 66 LAW Q. REV. 66, 229-52 (1950).

67. Crist, supra note 56, at 57. For accounts of the trial, see $R$. v. Harris, 7 COMPLETE Collection of State Trials 926 (T.B. Howell ed., London, Hansard 1816) (Feb. 5, 1680) [hereinafter STATE TRIALS]; A SHORT, BUT JUST ACCOUNT OF THE TRYAL OF BENJAMIN HARRIS (London, 1679) [hereinafter A SHORT, BUT JUST ACCOUNT]; Crist, supra note 56, at 54-57; Hamburger, supra note 56, at 685-86; and David Knott, The Booksellers and the Plot: Luttrell Pamphlets in the University of London Library, 23 BOOK COLLECTOR 194, 201-04 (1974).

The dating of $A$ Short, but Just Account depends on evidence from the collection of Narcissus Luttrell, an antiquarian, book collector, and member of Commons, who recorded the date of publication of each book or pamphlet he acquired after January 1, 1680. The pamphlet bears the date 1679 on its title page, but Luttrell's copy is dated " 7 Febr. 1679/80." STEPHEN PARKS, The LuTTREll FILE: NARCissus LuTTREll's Dates ON CONTEMPORARy PAMPHLETS 1678-1730, at 161 (1999). At that time, the new year began on March 25 (Lady Day), and to avoid confusion, dates between January 1 and March 24 were sometimes recorded by indicating both years, under the "Old Style" or "Lady Day dating." For evidence that Luttrell was recording the date of publication, see James M. Osborn, Reflections on Narcissus Luttrell (1657-1732), 6 BOOK COLLECTOR 15 (1957), reprinted in PARKS, supra, at 1. But see KNIGHTS, supra note 22, at 376 (arguing that in some instances, Luttrell recorded the date of purchase rather than the date of publication); Knott, supra, at $197-98$ (noting that Luttrell's notations are more likely to be accurate when they specify a particular date rather than a month). Besides listing the dates Luttrell 
a pro-exclusionist pamphlet, An Appeal from the Country to the City, ${ }^{68}$ which opposed James's succession and endorsed the King's illegitimate (but Protestant) son, the Duke of Monmouth. The jury sought to save Harris by returning a special verdict, "guilty of selling the book," but when directed to return with an unambiguous verdict of guilty or not, they found Harris guilty ${ }^{69} \mathrm{He}$ was sentenced to stand in the pillory and to pay a fine of $£ 500{ }^{70}$ Two other booksellers, Francis Smith and Jane Curtis, came before Scroggs on February 7 on similar charges. ${ }^{71}$ Both had been arrested the previous October for selling pamphlets alleging that Scroggs had been bribed in the trial of Sir George Wakeman. Having spent much of the intervening period in jail, Smith and Curtis both chose to admit their guilt and pay a $£ 10$ fine rather than suffer the same fate as Harris. ${ }^{72}$

Harris's prosecution inspired Hawles to amplify the lesson of Bushell's Case in The English-Mans Right, published on May 13, 1680. ${ }^{73}$ The pamphlet features a dialogue between a reluctant juror and a barrister who provides several references to the decision, complete with pinpoint citations in the book's margin. That Harris's trial prompted Hawles to write is apparent from the hypothetical examples he posits. As noted above, Harris's jury had sought at first to return a special verdict; however, the "great and Clamorous Shout" 74 their answer provoked from the audience was silenced when Scroggs threatened to poll the jurors individually, compelling them to produce the general verdict of guilty that he sought. ${ }^{75}$

assigned to each item in his collection, Parks's catalogue also includes Luttrell's other annotations.

68. [Charles Blount], AN APPEAl from the COUNTRY TO THE City, FOR THE PRESERVATION OF HIS MAJesties PERSON, LIBERTY, PROPERTY, AND THE PROTESTANT RELIGION (London, [Benjamin Harris] 1679).

69. A SHORT, BUT JUST ACCOUNT, supra note 67, at 7.

70. Crist, supra note 56 , at 57.

71. R. v. Smith, 7 STATE TRIALS, supra note 67, at 931 (Feb. 7, 1680); R. v. Curtis, 7 STATE TRIALS, supra note 67, at 959 (Feb. 7, 1680).

72. See Crist, supra note 56, at 57-61. Smith would be acquitted when tried for another charge of seditious libel in September. See infra notes $95-99$ and accompanying text. The doctrine of coverture would normally have protected Curtis from prosecution, but Scroggs, bent on punishing her, chose to accept the testimony of two witnesses that her husband, Langley Curtis, was dead. See SCHWOERER, supra note 56, at 94; Crist, supra note 56, at 58. In fact, Langley Curtis was alive and would himself be prosecuted unsuccessfully the following October. See infra text accompanying notes 95,100 .

73. PARKS, supra note 67, at 77. On the title page of Hawles's pamphlet, Luttrell wrote, "An ingenuous peice, \& worthy ye perusall of any who scrve yeir Country as a jury man." Id.

74. A SHORT, BUT JUST ACCOUNT, supra note 67 , at 7 . Scroggs was displeased:

I am sorry you gave countenance to this cause so much, as to stir from the bar, when the evidence was so full, and when I told you plainly, not only my opinion, but likewise that of all the judges of England, that selling this book was an offense at the common law, for which they ought to be punished; And yet with your scruples, you give the party (with their halloos and shoutings) to take advantage.... Would I knew some of those shouters, I would make them know, I would punish them ....

R. v. Harris, 7 STATE TRIALS, supra note 67, at 926, 931 (Feb. 5, 1680).

75. R. v. Harris, 7 STATE TRIALS, supra note 67, at 931. 
Without naming names, Hawles's dialogue addresses the same situation, positing the case of a defendant charged with treason for failing to doff his hat when passing a statue of the King. Asked what verdict he would support, the juror says, "[P]erhaps we would not bring him in Guilty generally, but only Guilty of the Fact, Finding no more but Guilty of passing by the Statue with his Hat on." 76 The barrister, somewhat misrepresenting the details of Harris's case, replies that "such a finding hath generally been refused by the Court, as being no Verdict." 77 Having seen a defendant victimized once by this strategy, Hawles sought to prevent its recurrence.

This hypothetical provides the model for numerous examples that would follow in later pamphlets on the jury's power. In illustrating the merger of law and fact, commentators would frequently propose an example in which the prosecution is framed by welding a malicious or seditious intent to an innocent act (such as publishing the $\mathrm{Bible}^{78}$ ), and would then ask whether anyone could return a guilty verdict in such a case.

This tactic amounts to an argument for nullification rather than the more limited capacity for jury independence that Vaughan had defended. As noted above, Vaughan never allowed that the jury may rule against its own view of the evidence. Hawles, however, would ask the jury to weigh the legal basis for the indictment itself, and to reject the policy if they found it offensive. Tellingly, the proponents of nullification often proceeded by invoking the "personal knowledge" claim as a later step in the argument rather than simply asserting that the libel prosecutions were illegitimate. This pattern, often repeated in the literature, makes the claim for local knowledge appear particularly specious, hence raising questions about the function it served. Hawles usefully provides an early example of this strategy.

Although Hawles went beyond Vaughan's argument for jury independence, The English-Mans Right otherwise tacks closely to Vaughan's opinion, most significantly by focusing on the same jury that figured in Bushell's Case-the petit jury. Hawles never stopped to explain this decision; he probably never thought to explain it since Harris's case, like Bushell's, turned on the verdict of a petit jury. On the question of the jurors' personal knowledge, Hawles's barrister remarks that the defendant's "neighbours (who consequently cannot be presumed to be unacquainted either with the matters charged, the Prisoner's course of life, or the credit of the Evidence) must first be fully satisfied in their Consciences, that he is guilty." 79 This brief statement hardly achieves the stridency of later

76. HAWLES, supra note 62 , at 16.

77. Id.

78. See, e.g., infra text accompanying note 144.

79. HAWLES, supra note 62 , at 7 . 
commentators on the issue, but in arguing that the jurors' independent judgment is bound up with their personal knowledge of the case, Hawles developed Vaughan's discussion, if only slightly, by couching his explanation in the language of a verdict according to conscience and hinting at a standard of guilt beyond a reasonable doubt. Repeating Vaughan's remarks on the relation between law and fact, Hawles also argued that "in most General issues, as ... in trespass, breach of the peace, or Felony, ... the Jury do not find the Fact of the case by it self, leaving the Law to the Court, but find the party guilty, or not guilty, generally." ${ }^{80}$ Here, then, along with the motto that jurors must attend to "matter of Law, as it arises out of, or is complicated with, and influences the Fact," 81 we find the suggestion that law-finding is routinely a duty of the jury. Hawles dignified the argument by purporting to derive it from Littleton and Coke. ${ }^{82}$

The discussion of Bushell's Case itself forms a significant part of the pamphlet. Hawles introduced the case halfway through his dialogue, and the discussion takes up most of the remainder of the tract, turning the dialogue into a monologue by the barrister. Hawles's first reference to the case is also his most dramatic: When the juryman worries that a disobedient verdict might result in a fine that would "utterly ruin ones Family," the barrister declares, in the pamphlet's only typographical shift into a gothic, black-letter font, that "there is never a judge in England that can Fine or Imprison any Jury-man in such a Case." ${ }^{83}$ In explicating the decision, which he quoted at length, Hawles briefly revisited the vicinage argument (" "To what end must Hundredors be of the Jury, whom the Law supposeth to have nearer knowledge of the Fact than those of the Vicinage in general?", ${ }^{84}$, which he connected to the relation between law and fact:

As the Judge can never direct what the Law is ... without first knowing the Fact, so he cannot possibly know the Fact but from the Evidence which the Jury have; but he can never fully know what Evidence they have, for besides what is sworn in Court, (which is

80. Id. at 11 ; see supra text accompanying note 36 .

81. HAWLES, supra note 62 , at 10.

82. See id. at 11 " But to put the business out of doubt, we have the suffrage of that Oracle of Law Littleton, who in his Tenures, Sect. 368. declares, That if a Jury will take upon them the knowledg of the law upon the matter, they may. Which is agreed to, likewise by Cook in his Comment thereupon."). Hawles's characterization is not entirely accurate: Littleton states that in those cases in which the jury " "may give their verdict at large, if they will take upon them the knowledge of the law upon the matter, they may give their verdict generally." 2 EDWARD COKE, ThE FiRST PART OF THE INSTITUTES OF THE LAWS OF ENGLAND 228a (Charles Butler ed., London, J. \& W.T. Clarke 18th ed. 1823) (1628) (quoting Littleton). In his commentary on this passage, Coke observed that "it is dangerous for them so to doe, for if they doe mistake the law, they runne into danger of an attaint; therefore to find the speciall matter [i.e., a special verdict] is the safest way where the case is doubtfull." $I d$.

83. HAWLES, supra note 62, at 24; see also infra text accompanying note 112.

84. HAWLES, supra note 62, at 26 (quoting Bushell's Case, 124 Eng. Rep. 1006, 1012 (C.P. $1670)$ ); see supra text accompanying note 47 . 
all that the Judge can know) the Jury being of the Neighbourhood, may, and oft-times do know something of their own knowledge, as to the Matter it self, the Credit of the Evidence, \&c. which may justly sway them ....85

At the same time, Hawles also emphasized the unanimity requirement, insisting that each juror must be "satisfied in his particular Understanding and Conscience." 86 Although he passed up the opportunity to repeat Vaughan's remarks about the subjectivity of individual perception, Hawles approvingly quoted Vaughan's statement that every juror is entitled to "differ in Judgment from his Fellows... though his dissent may not in truth be as reasonable as the Opinion of the rest that agree." ${ }^{87}$

Hawles's attempt to publicize Vaughan's opinion came at an opportune moment. Published three months after Harris's trial, The English-Mans Right clearly anticipated further difficulty from Scroggs, whom it singled out as personally bound by the holding of Bushell's Case, because "[Vaughan's] Book of Reports is approved and recommended to the World (as appears by the Page next after the Epistle) by the Right Honourable the present Lord Chancellor of England, Sir William Scroggs, now Lord Chief Justice of England." 88 The summer and fall of 1680 witnessed a continuation of the campaign against seditious libel, with consequences that persuaded Hawles to write a sequel devoted to the grand jury. In July, two months after The English-Mans Right was published, Scroggs tried two more booksellers-Elizabeth Cellier and Henry Care. Cellier managed to discredit the leading witness for the prosecution, ${ }^{89}$ but Care was found guilty for a libel published in his paper, The Weekly Packet of Advice from Rome ${ }^{90}$ Relying on a new view of the King's authority to control the press in the absence of statutory regulation, Scroggs helped the jury reach a guilty verdict by instructing them that Care's guilt hinged not on the presence of malicious intent, but on whether he had published the pamphlet without having it licensed. ${ }^{91}$ Despite being found guilty, however, Care was not

85. HAWLES, supra note 62, at 29.

86. Id. at 38 .

87. Id. (citing Bushell's Case, 124 Eng. Rep. 1006, 1014 (C.P. 1670)).

88. Id. at 34 .

89. R. v. Cellier, 7 STATE Trials, supra note 67, at 1043, 1051 (July 11, 1680). Later that year, Cellier was anrested again for seditious libel and was found guilty at her trial in September. She was fined $\$ 1000$ and was pilloried three times. For the trial, see $R$. v. Cellier, 7 STATE TRIALS, supra note 67, at 1183 (Sept. 11-13, 1680). See also Penny Richards, A Life in Writing: Elizabeth Cellier and Print Culture, 7 WOMEN's WRITING 411 (2000) (discussing Cellier's trials in the context of her career as a bookseller and writer).

90. R. v. Care, 7 STATE TRIALS, supra note 67, at 1111, 1121, 1130 (July 2, 1680).

91. Hamburger notes that Care's case established the basis for "[s]o-called "seditious libel" trials for unlicensed publishing of news during the remainder of Charles' reign." Hamburger, supra note 56, at 689 . A recent ruling had confirmed that the King might " "prohibit the printing \& publishing [of] all News Bookes \& Pamphletts of News whatsoever not licenced by [his] Authority as Manifestly tending to the Breach of the Peace \& Disturbance of the Kingdome""; as 
punished ${ }^{92}$ and he continued to publish the Weekly Packet until 1683, surviving a series of government attacks on opposition papers. ${ }^{93}$ Indeed, he used his paper to discuss the ignoramus juries that provoked the government throughout $1681 .^{94}$

\section{B. The Rise of Ignoramus and Hawles's Second Pamphlet}

Care's trial did not immediately provoke further discussion of jury nullification, but it was soon followed by the first set of ignoramus bills, returned by grand juries in September 1680. Three booksellers-Francis Smith, Langley Curtis, and David Mallett-were prosecuted for seditious libel in September, and all three prosecutions were halted by ignoramus bills. ${ }^{95}$ Smith, the first to be prosecuted, appeared before Lord Chief Justice Jeffreys on September $16,1680,{ }^{96}$ and was charged on the basis of a pamphlet recommending that the Lord Mayor of London limit his expenses for public feasts. ${ }^{97}$ The charge was dismissed three times successively by the same grand jury, whose presentments Jeffreys effaced twice before abandoning that tactic and calling Smith into court to demand a confession. ${ }^{98}$ Smith, however, answered that "no Law Commands me to

a result, Hamburger explains, "most of the 'seditious libel' trials between 1680 and 1685 were not for libel but for the publishing of books of news without license, contrary to the declared prerogative of the king." Id. at 687 (quoting Opinion of May 5, 1680 (P.C.) (on file in the Public Records Office, London, P.C. 2/68)).

92. See SCHWOERER, supra note 56 , at 125 .

93. For a useful discussion of the opposition newspapers during the early 1680 s, see JAMES SUTHERLAND, THE RESTORATION NEWSPAPER AND ITS DEVELOPMENT 19-20, 201-04 (1986).

94. Care's articles, which ran in the latter part of 1681, provoked an angry response from an anonymous pamphleteer for the government. See Some Queries for Mr. Care To Chew, Relating to His Ignoramus Juries, in A POSTSCRIPT OF ADVICE FROM GENEVA, TO BE ADDED TO EACH OF MR. CARE'S SEVERAL VOLUMES OF ADVICE FROM ROME 7 (London, 1681). The pamphlet asked:

Whether a Perjur'd Pillory'd Thief, Begger, Fool or Knave, be not as good Evidence against a Whig, as against a Papist? Whether, had it not been for People so qualified, we had ever known of a Popish-Plor? ... Whether, if an Highway-man was to be tryed by a Jury of his own Gang, they would not act more like brute Beasts than rational Creatures, if they found the Bill? Whether there is not just ground for suspicion of Guilt in the Prisoner, when his Friends are forc'd to pick up Jury-men (contrary to custom) from one end of Town to the other?

Id. at 7-8. The "Pillory'd Thief" probably refers to Benjamin Harris, who was pilloried in 1680 . See supra text accompanying notes 67-70.

95. Crist, supra note 56 , at 64-65.

96. Id.

97. AN ACT OF COMMON-COUNCILL OF THE CITY OF LONDON FOR RETRENCHING OF THE EXPENCES OF THE LORD MAYOR \& SHERIFFS (London, Francis Smith 1680).

98. AN ACCOUNT OF THE INJURIOUS PROCEEDINGS OF SIR GEORGE JEFFREYS KNT. LATE RECORDER OF LONDON, AGAINST FRANCIS SMITH, BOOKSELlER 4 (London, Francis Smith [1681]) [hereinafter INJURIOUS PROCEEDINGS] (stating that "[t]he Jury ... had the bill brought them in again, with their Ignoramus scraped out, as the Jury have since declared"). Although this pamphlet was published without a date, the copy in the Harvard University Library, which has been reproduced in the Early English Books Online database, see Early English Books Online, at http://wwwlib.umi.com/eebo (last visited Feb. 7, 2002), bears a date of " 1 Febr. 1681/0" in a 
accuse myself," 99 and thanked the jury. On September 17, 1680, Curtis and Mallett were prosecuted for publishing Old Bailey sessions reports in violation of the judges' prerogative to license such publications. Again, Jeffreys effaced the first ignoramus bill, but he capitulated when the jury returned the same answer a second time..$^{100}$

The following month, on October 26, Hawles published his second pamphlet, The Grand-Jury-Man's Oath and Office Explained ${ }^{101}$ at around the same time, a second edition of The English-Mans Right was advertised for sale. ${ }^{102}$ Written in dialogue like its precursor, The Grand-Jury-Man's Oath and Office Explained was about half the length of Hawles's earlier pamphlet and was issued by none other than Langley Curtis, who was back at work after his trial. ${ }^{103}$ Except in the title, Hawles never explicitly differentiated between the petit and grand juries, but he assumed the distinction throughout-a feature that explains many of the differences between the two pamphlets, most notably the absence of any explicit reference to Bushell's Case in the second pamphlet. Further, although Hawles had argued in The English-Mans Right for the power to nullify, The Grand-Jury-Man's Oath relies on the more limited understanding of jury independence that Vaughan had addressed in Bushell's Case. In treating the

contemporary hand. Though this is not the usual way of representing dates according to the "Old Style," see supra note 67, the inscription seems to indicate a publication date of February 1, 1681.

99. INJURIOUS PROCEEDINGS, supra note 98, at 5; see also FRANCIS SMITH, AN IMPARTIAL ACCOUNT OF THE TRYAL OF FRANCIS SMITH (London, [1681]) (giving Smith's version of the trial). Luttrell dates Smith's pamphlet to February 9, 1681. PARKS, supra note 67, at 162.

100. Crist, supra note 56 , at 65 (stating that " [t]he original indictments show that Jeffreys presented each bill a second time after the ignoramus verdicts" and that "the word [ignoramus] was rubbed out before the second presentation" (citing LONDON SESSIONS RECORDS, 1605-1685, at 297 n. (Hugh Bowler ed., 1934))).

101. HAWLES, supra note 63; see PARKS, supra note 67, at 77; see also 1 EDWARD ARBER, The Term Catalogues, 1668-1709 A.D., at 417 (1903) (listing an advertisement dated November 1680 for The Grand-Jury-Man's Oath). The Term Catalogue was a quarterly publication of the book trade, listing new and newly reprinted books.

102. See 1 ARBER, supra note 101, at 424 (listing an advertisement dated November 1680 for an edition of The English-Mans Right published by D. Newman). Although no copies of this edition are known to survive, the advertisement is not necessarily fictitious: Dorman Newman was a prominent bookseller who issued numerous publications representing Whig views. See Elizabeth L. Furdell, "At the King's Arms in the Poultrey": The Bookshop Emporium of Dorman Newman 1670-1694, 23 LONDON J. 1 (1998).

103. See HAWLES, supra note 63. The Grand-Jury-Man's Oath is twenty-three pages long; The English-Mans Right, by comparison, is forty pages. Curtis may have solicited the pamphlet as a result of his trial; Hawles's earlier pamphlet, see HAWLES, supra note 62, was issued under the imprint of Richard Janeway, another prominent Whig bookseller. See infra note 138. It should be noted, however, that both Janeway and Curtis acted as "trade publishers," issuing books under their own names when in fact they were only acting as distributors in order to disguise the identity of the true publisher. See Michael Treadwell, On False and Misleading Imprints in the London Book Trade, 1660-1750, in FAKES AND FRAUDS: VARIETIES OF DECEPTION IN PRINT \& MANUSCRIPT 34 (Robin Myers \& Michael Harris eds., 1989) (listing Janeway and Curtis among those whose "presence ... is an almost certain guarantee that that imprint is . . . a misleading one and that the work on which it appears was actually published (in our modern sense) by someone else"). Hence both of Hawles's pamphlets may actually have been published by another, unnamed member of the bookselling industry. 
grand jury as a separate institution, Hawles observed a distinction that would be ignored a year later by the Whig polemicists defending the grand juries' ignoramus bills in the treason cases. Even in its abbreviated form, however, the defense of jury independence in The Grand-Jury-Man's Oath addresses several topics that would resurface frequently in later treatments of nullification. Thus, for example, Hawles focused on the part of the juror's oath stating that he will "diligently Inquire and true Presentment make," explaining that jurors are thereby instructed "to Enquire, and that diligently, not to be slothful, or negligent, not to take things upon Trust, or hurry them over carelessly" 104 - an explanation that other commentators would repeat almost verbatim. ${ }^{105}$ On the other hand, in quoting the oath's demand that jurors "Present the Truth, the whole Truth, and nothing but the Truth," ${ }^{106}$ Hawles associated this pledge with a probable cause requirement, describing a lower proof standard than one would expect to find in a robust argument for nullification: "They [the grand jurors] ... cannot be intended to give in more than a verisimilary or probable Charge; which by what they have heard, they do aver upon their Oaths, does seem to them to be Just and true, and fit for Justice to take Cognizance of." ${ }^{107}$ The grand jurors' bill, Hawles explained, "denotes not an absolute Certainty, but so as things appear." 108

Most of the pamphlet, however, is devoted to the law/fact distinction, centering on the example of seditious libel. Hawles complained that in libel prosecutions, language about intent is often "thrust in to raise a pretence or colour of Crime, where there is really none." ${ }^{109}$ Hawles formulated this argument only in skeletal form: Far from suggesting that law and fact are typically so intertwined as to become equally matters of jury discretion, he reserved that principle for a limited set of cases, acknowledging that where the law, by a "Just and reasonable implication," defines an act as the effect of malicious intent, the grand jury is "bound" to find intent where it finds the act, even where no "direct proof" has been offered to establish intent." ${ }^{110}$ Hawles treated this view as uncontroversial, but it would not meet with such ready assent among later commentators.

104. HAWLES, supra note 63 , at 5 .

105. See, e.g., HenRy CaRe, English Liberties: Or, The FreE-Born SubJect's INHERITANCE 214-15 (London, G. Larkin for Benjamin Harris [1682]). For the dating of this treatise, see infra note 160 .

106. HAWLES, supra note 63 , at 7 .

107. Id. at 9 .

108. Id.

109. Id. at 17 .

110. Id. The pamphlet states:

Where the Act, or matter of Fact charged, is in it self a Crime or offence against Law . . . and If the Jury do find and are satisfied, That the substance of the Charge is such a crime,... They are bound to find $i t$, though no direct proof be made of those Id. Circumstancials. 
His defense of nullification was similarly brief, if more uncompromising. In response to the anxiety that jurors might be "Fine $[d]$ or Imprison[ed]" for returning a bill "according to the best of their Understanding and Consciences," the barrister cryptically but firmly announces that "[t]he Law utterly Condemns any such Practice." 111 Rather than citing precedent for this assertion, Hawles referred his reader to the page featuring the black-letter discussion of Bushell's Case in his earlier pamphlet: "[Y]ou may see [this] undeniably proved in...The English man's Right, p. 24." ${ }^{112}$ Evidently written in anticipation of further seditious libel prosecutions, The Grand-Jury-Man's Oath is interesting in part because of the modesty of its claims: It does not purport to provide a genealogy of the "ancient" rights of juries, nor does it recommend nullification as a general remedy available for most cases. Moreover, Hawles made no effort to credit the grand jury with any personal knowledge about the cases it hears. To say that the jurors can "present ... the whole Truth" by judging a charge to be "verisimilary or probable," rather than by determining its absolute truth, is to raise the possibility that they may lack access to the evidence that would allow for a higher proof standard.

Hawles's tract seems to have provoked little immediate response, but among the few who did take up the question was Benjamin Harris. In late November, evidently heartened by the turn of events in the fall, Harris printed a leaflet advocating jury nullification, titled Twenty Four Sober Quceries Humbly Offered To Be Seriously Considered by All Juries in City and Countrey. ${ }^{113}$ Harris may also have written the leaflet, which was not signed, but which carried his name as the printer. Without citing Bushell's Case itself, the leaflet poses a string of questions that resonate with Hawles's arguments in The Grand-Jury-Mans Oath and The English-Mans Right. The list includes such questions as "Whether a Jury is not bound by their Oaths and Conscience to consider and very seriously enquire into every part of the Indictment or Information," 114 and "Whether a Jury is not bound in Conscience by their Oaths to consider and compare the Evidence

111. Id. at 22 .

112. Id. For Hawles's discussion of Bushell's Case in The English-Mans Right, see supra text accompanying note 83 .

113. TWENTY FoUR SOBER QUARIES HuMbly OFFERED TO BE SERIOUSLY CONSIDERED BY ALL JURIES IN CITY AND COUNTREY (London, Benjamin Harris 1680) (hereinafter TWENTY FOUR SOBER QUARIES]. This leaflet is undated and does not appear in PARKS, supra note 67. The copy in Early English Books Online, supra note 98, however, reproduced from the copy in the Harvard University Library, bears a date of " 27 Nov. 1680," and Stephen Parks, curator of the Osborn Collection at Beinecke Library, Yale University, has confirmed that the date is in Luttrell's handwriting. E-mail from Stephen Parks, Beinecke Library, Yale University, to author (Mar. 30, 2001) (on file with author).

114. TWENTY FOUR SOBER QUERIES, supra note 113, at 1; see supra text accompanying note 104 . 
with the particulars in the Indictment or Information." 115 In contemplating an actively resistant jury, the author indicated the path that later commentators would take.

The leaflet ends by addressing the legitimacy of judges' behavior, asking whether they are not required to

compare the Facts of the Indicted person with the Laws, and to make it plain to the Jury and all that come to see Justice done, that the person Indicted is not falsly but truly Indicted, respecting the matter of Fact ... that so if the person be found guilty by the Jury, he may be convinced in his own Conscience that his Judgment is just, as also that those which hear may be Informed and fear to Transgress? ${ }^{116}$

Without spelling out a remedy for the jury to adopt in the absence of such an open and well-grounded prosecution, the leaflet seems to hint that nullification is an appropriate response to the appearance of arbitrariness. In a short work, simply designed to be provocative, one would hardly expect to find a fully elaborated account of this theory. The leaflet suggests, however, that jurors are entitled not only to have the law made clear to them, but also to be persuaded of its basis and validity. The judge himself thus resembles a witness whose testimony is subject to sifting and probing by jurors who are free to reject it if they find it inadequate. Although the argument for legitimacy appears here only fleetingly, it targets an aspect of jury nullification that would receive more attention as the debate continued.

\section{THE 1681 TREASON TRIALS}

The next set of arguments concerning jury nullification erupted around the trial of Stephen Colledge. Charged with treason, Colledge was exonerated when a London grand jury returned an ignoramus bill in June 1681-an action that the Tory polemicists had anticipated and that brought the discussion of Bushell's Case to a new level. Although Roger L'Estrange was not the only Tory journalist to be outraged by the decision, he was particularly vocal in his criticism, which provoked Colledge's Whig supporters to respond in kind. Near the end of the year, two of the other alleged conspirators against the King-John Rouse and the Earl of Shaftesbury-were also spared by ignoramus bills. Between the summer of 1681 and the fall of 1682 , the Whigs worked intensively to exploit Hawles's arguments and to develop new ones in favor of jury nullification. Although the "personal knowledge" argument figured prominently in these

115. TWENTY FOUR SOBER QUERIES, supra note 113 , at 1.

116. Id. at 2 . 
writings, the Whigs also treated the merger of law and fact as a common occurrence and argued that, while judges were political appointees who needed to please the Crown in order to stay in office, juries had no such political dependencies. ${ }^{17}$ In adapting and expanding on Hawles's arguments, these polemicists crafted a defense of nullification that would become highly influential; two of the treatises produced during this phase of the debate - one by John Somers and one by Henry Care-went through several reprints in England and the American colonies during the next century and helped preserve the vicinage argument into the late eighteenth century.

\section{A. The Trial of Stephen Colledge and the Tory Response}

To understand the context in which the nullification debate escalated, it is useful to begin with an overview of the political conflict during the spring and summer of $1681 .{ }^{118}$ King Charles summoned Parliament to meet in Oxford on March 21 and dissolved that body a week later, citing allegations of a Whig conspiracy to kidnap him in order to secure his consent to the Exclusion Bill. ${ }^{119}$ This story was concocted by a pair of Whig informers with highly fluid political allegiances, who sought to protect themselves by currying favor with the Crown. One of the informers, Edward Fitzharris, had been charged with writing a treasonous libel against the King ${ }^{120}$ and hoped to be spared if he could make himself useful to the King's party. That ploy failed, ${ }^{121}$ but when Fitzharris was hanged on July 1 , his story was confirmed by Bryan Haines, whom the Earl of Shaftesbury

117. The question of the judiciary's dependence on the Crown provoked a significant amount of debate during this period. See David Lemmings, The Independence of the Judiciary in Eighteenth-Century England, in THE LIFE OF THE LAw: PROCEEDINGS OF THE TENTH BRITISH LEGAL History CONFERENCE 125 (Peter Birks ed., 1993).

118. The summary in the following paragraphs draws on RICHARD L. GREAVES, SECRETS OF THE KINGDOM: BRITISH RADICALS FROM THE POPISH PLOT TO THE REVOLUTION OF 1688-1689, at 22-42 (1992); HARTH, supra note 24, at 62-102; KNIGHTS, supra note 22, at 96-103; and ZOOK, supra note 24, at 88-91. For discussions that focus specifically on the ignoramus bills, see ROGER NORTH, EXAMEN: OR, AN ENQUIRY INTO THE CREDIT AND VERACITY OF A PRETENDED COMPLETE HISTORY 189-214 (London, Fletcher Gyles 1740), which discusses the presentments of Colledge, Rouse, and Shaftesbury; and John Kinghorn, The Growth of the Grand Jury System, 6 LAW MAG. \& REV. (4th ser.) 367, 375-81 (1880), which discusses the ignoramus bills in relation to contemporaneous arguments over the secrecy of the grand jury.

119. According to Edward Fitzharris, as reported by Francis Hawkins, the conspirators "had 60000 Men at command, at very short warning," and the leaders "would have obliged [King Charles] to call a Parliament, which should sit until the Bill of Exclusion against the Duke [of York] was passed"; they also wanted control over the government, including "the Militia ... and the Navy." Francis Hawkins, A Narrative: Being a True Relation of What Discourse PASSED BETWEen DR. Hawkins AND EDWARd FITZ-HaRYS, ESQ. 4 (London, Samuel Carr 1681).

120. See Proceedings in Parliament Against Edward Fitzharris, 8 STATE TRIALs, supra note 67, at 225 (Mar. 25-26, 1681).

121. See R. v. Fitzharris, 8 STATE TRIALS, supra note 67, at 330, 391 (K.B. June 9, 1681). 
had imported from Ireland as a witness to yet another alleged Catholic conspiracy against the Protestants. Haines had been arrested in June, and Shaftesbury himself was arrested for treason the day after Fitzharris's execution. At this point, Haines seconded Fitzharris's allegations and implicated John Rouse (who had provided the funds to maintain Haines in London) and Stephen Colledge as conspirators.

Colledge had already made a name for himself as an author of antiCatholic ballads; ${ }^{122}$ when Parliament met in Oxford, Colledge traveled there, "ostentatiously displaying weapons and ... speaking threateningly against the king." 123 At the first presentment of the charges against Colledge on June 8, a Whig-dominated grand jury returned an ignoramus bill, which provoked outraged complaints from the Tories. An anonymous pamphleteer, intoning his argument in cadences that might have been inspired by Vaughan's opinion itself, sarcastically purported to credit the jury's honesty: "Suppose the Evidence clear and positive against Colledge, yet we cannot be assured it appeared so the Gentlemen of the Grand-Jury. Every one has his failings, and some cannot see the Sun shine at noonday." "The government responded by removing the trial to Oxford, since some of Colledge's actions occurred there. In a letter to the official entrusted with selecting the jury pool, the Secretary of State asked for "a good, honest, substantial grand jury ... consist[ing] of men rightly principled for the Church and the King." ${ }^{125}$ Colledge was promptly indicted by a grand jury in Oxford on July 14, and the trial jury there found him guilty a month later; he was hanged on August $31 .{ }^{126}$ Rouse and Shaftesbury were more fortunate: When each secured an ignoramus bill

122. See, e.g., [STEPHEN COLlEDGE], A SATYR AGAINST IN-JUSTICE ([London], [1679]). Luttrell dated this leaflet to 1679 , but did not date it more specifically. For the copy dated by Luttrell, see STEPhEN COlledge, A SATYr AGAinst IN-JUSTICE (London, 1679) (copy in Newberry Library, Chicago, case 6A 158, no. 46). This ballad was published anonymously. For the attribution to Colledge, see 4 DICTIONARY OF NATIONAL BIOGRAPHY 788 (Leslie Stephen \& Sidney Lee eds., Oxford Univ. Press 1993) (1882).

123. 4 DICTIONARY OF NATIONAL BIOGRAPHY, supra note 122, at 788.

124. A MODEST VindiCATION OF THE PROCEEDINGS OF THE LATE GRAND-JURY AT THE OLD BAILY 1 (London, Nathaniel Thompson 1681); see also A LETTER FROM THE GRAND-JURY OF OXFORD TO THE LONDON-GRAND-JURY 1 (London, Allen Banks 1681) ("We much admire how you [i.e., the London jury] could salve the Reason and Dictates of your Consciences, in acquitting a notorious Traytor in a publick Court of Judicaturc; that had so abominably affronted Our Excellent King, by such Words and Actions, in so many Seditious Coffee-houses ...."). The coffeehouses, an invention of the 1660 s, were generally viewed by the government as hotbeds of sedition. See Steve Pincus, "Coffee Politicians Does Create": Coffeehouses and Restoration Political Culture, 67 J. MOD. HIST. 807, 826 (1995).

125. Letter from Sir Leoline Jenkins to Lord Norreys (July 11, 1681), in 22 CALENDAR OF STATE PAPERS, DOMESTIC SERIES 353 (F.H. Blackburne Daniell ed., Kraus Reprint Ltd. 1968) (1921).

126. See R. v. Colledge, 8 STATE Trials, supra note 67, at 549 (Aug. 17, 1681); Harth, supra note 24 , at $91-92$. 
after their presentments in October and November, respectively, ${ }^{127}$ the government dropped both cases.

Although these two later bills would provoke further controversy, Colledge's presentment in London brought the nullification debate to a head. In the July 7 issue of the Observator, Roger L'Estrange anticipated that the London grand jury might refuse to indict Colledge. ${ }^{128}$ L'Estrange staged a dialogue between a righteous Tory, incensed at the perversion of justice wrought by the ignoramus juries, and a self-incriminating Whig who functions as a kind of ventriloquist's dummy, brazenly displaying his own lack of principle and incriminating himself at every turn. Rather than being permitted to rehearse the pro-nullification arguments of Hawles and Harris, L'Estrange's Whig is made to acknowledge that such behavior is unlawful. Confronted with the question "what Punishment can the Law Inflict upon a Jury-man, that shall bring in an Ignoramus, upon a Clear and Point-Blank Evidence," the Whig obediently explains that such conduct is "Finable, and Penall." ${ }^{229}$ L'Estrange ignored Bushell's Case, perhaps intending by his remarks to mark the difference between a grand jury hearing an ex parte case and a petit jury like Bushell's. By the end of the year, he would clarify that distinction more explicitly; ${ }^{130}$ at this point, however, he simply emphasized the grand juries' lawlessness. In a paper published the week after Colledge's exoneration by the London grand jury, L'Estrange scolded those who would justify such an act by an appeal to personal conscience, insisting that "you do not live in Conformity to the Law, Unless ye submit to such Judges of the Law, as the Law it self has appointed." 131 After continuing in this vein for several paragraphs, the Tory interlocutor concludes:

[I]f ever any Jury should bring in an Ignoramus upon such an Instance as is here supposed; that is to say, upon Severall Treasons, Sworn, and clearly made out by several Competent Witnesses: No Punishment, I say, nor any Censure could be too severe for such a Jury. But now it comes in my head; what became of the Bill against Mr. Colledge? ${ }^{132}$

127. See A Particular account of the Proceedings at the Old-Bayly, the 17 \& 18 OF THIS INSTANT OCTOBER (London, Thomas Newcomb 1681) (discussing Rouse's presentment); Proceedings at the Old-Bailey, upon a Bill of Indictment for High Treason, Against Anthony, Earl of Shaftesbury, 8 STATE TRIALS, supra note 67, at 759, 760 (Nov. 24, 1681) (discussing Shaftesbury's presentment); id. at 759, 821 (discussing Shaftesbury's ignoramus bill).

128. [Roger L'Estrange], OBSERVATOR IN DialogUE, July 7, 1681, at 1.

129. Id. at 2 (emphasis altered).

130. See infra note 136.

131. [Roger L'Estrange], OBSERVATOR IN DIALOGUe, July 13, 1681, at 2.

132. Id. 
His question, whose answer was by that time well-known, meets with embarrassed silence. Despite his frequent attacks on the ignoramus juries, however, L'Estrange only occasionally attacked the principle of jury nullification, instead devoting most of his energy to the claim that the Whig grand juries' actions were purely political. ${ }^{133}$ In these attacks, he resembles Edward Rawlins, the Tory journalist who published Heraclitus Ridens, ${ }^{134}$ another paper that railed constantly against the ignoramus juries by expressing mock astonishment at the flexibility of the term "conscience" in the Whigs' mouths. ${ }^{135}$ When these polemicists addressed the policy arguments concerning nullification, they turned most readily to the distinction between the petit and grand juries, and emphasized the different competences that Hawles, if not Harris, also observed: Grand juries, according to these Tory journalists, have no charge to evaluate the credibility of the witnesses they hear. ${ }^{136}$

In one instance, however, L'Estrange specifically attacked the policy underlying the theory that law and fact are inseparable. After making his Whig complain that when malicious intent forms part of the indictment, "a Person might come to be Condemn'd for the most innocent fact in the world," L'Estrange responded with a policy argument that, for him, demonstrated that juries should never be trusted to evaluate intent: "It is the Law Judges of that Traiterous and Malicious Intention; for otherwise a Jury of Covenanters would never find any man guilty of Treason, or Malice, for Endeavouring to Subvert the Government; since by that Covenant, the Government was Subverted, under a Pretence of Religion, and Obedience." ${ }^{137}$ L'Estrange countered the Whig argument for jury lawfinding with an equally extreme alternative: Where law and fact are bound

133. See, e.g., [Roger L'Estrange], OBSERVATOR IN DiALOGUE, July 16, 1681, at 1 ('“ [Whig]: [I]f the Law must not yield, and our Consciences cannot, what's to be done? [Tory]: Obey or Suffer: But that's not the Point neither; for your Consciences will work like Wax ...."); [Roger L'Estrange], OBSERVATOR IN DIALOGUE, Dec. 17, 1681, at 1 (“[Tory]: [P] the Case now, that the Six men of the whole world that you would least believe, should Swear Oates, and L'Estrange to be a Couple of Jesuites... . [Whig]: If I were of the panel, I would return Ignoramus upon Oates, and find the Bill upon L'Estrange.").

134. This newspaper was published anonymously. Its authorship was established in Theodore F.M. Newton, The Mask of Heraclitus: A Problem in Restoration Journalism, 16 HARV. STUD. \& NOTES PHILOLOGY \& LITERATURE 145 (1934).

135. See, e.g., [Edward Rawlins], HERACLITUS RIDENS, July 19, 1681, at 1 ("Ignoramus is . . a man of Prodigy and Wonder, nay they say he is even astonished at himself.").

136. See, e.g., [Roger L'Estrange], OBSERVATOR IN Dialogue, Dec. 17, 1681, at 1 ("[Whig]: Every Witness is not presently Credible, because the Law has Judg'd him competent. [Tory]: You run all this while upon a mistake, for want of Distinguishing betwixt the Office of a Grand, and of a Petty-Jury. The Credibility, of the Evidence is not your Business, but the Matter that is sworn...."); [Edward Rawlins], HeRACLITUS RIDENS, July 26, 1681, at 2 ("[T] he Business of a Grand Inquest seems to be ... only to find that such matter of Fact was sworn, which is sufficient ground to find any Bill; and here their Consciences could have no doubt, the Petit Juries Consciences being by Law the proper Judges of the Credibility of Circumstances and Evidence ....").

137. [Roger L'Estrange], OBSERVATOR IN Dialogue, Nov. 26, 1681, at 2. 
together, the judge may decide both. The policy argument, of course, is equally troubling on either side, insofar as it simply withdraws control from one of the authorities in the trial rather than seeking to divide the power. What L'Estrange accurately registered, however, is the problem that the "exception" for jury law-finding quickly becomes a general license. More generally, this argument also illustrates the lack of subtlety in his attacks on nullification. To seek carefully thought-out anti-nullification arguments in the Observator is a mistake: L'Estrange was concerned primarily with discrediting his Whig opponents, and only secondarily with the theories on which they relied. Although he occasionally considered the broader implications of their arguments, his paper contributed most saliently to the debate simply by forcing the opposition to clarify its arguments.

\section{B. The Whig Defense of Nullification}

One of the commentators who took up L'Estrange's challenge was the author of the anonymous pamphlet The Power and Privilege of Juries Asserted ${ }^{138}$ whose sub-subtitle (Published for the Information of Heraclytus Ridens, and the Doting Observator) indicates the motive for its publication. Unlike Hawles, the author focused mainly on the fairness of allowing jurors to act according to their consciences. Thus, the author argued that to deny jurors the ability to nullify would turn them into much more reluctant participants, harming the jury system itself:

It puts Juries upon these Dilemma's either to serve or not to serve[;] if they refuse to serve, they lose Issues, and are punished that way: if they do serve, then they must find according to their Consciences or not: if according to their Consciences, then they offend the Judg, if it be against his Direction, and such Evidence as seems so to him, and so they incur Fine, Imprisonment, and consequently Death, Temporal Punishments: If not according to their Consciences, then they offend God, and incur Punishments both Temporal and Eternal. ${ }^{139}$

The pamphlet also emphasizes the symmetry between judges and jurors: "Juries are as ancient as Judges, and ... the same Law that ordained both Judges and Juries gave them divisum imperium, a divided Authority, and

138. The POWER AND PRIVILEGE OF JURIES ASSERTEd (London, Richard Janeway 1681). The pamphlet was probably published in June or July; Rawlins mentioned it in an attack on Janeway published in late July. See [Edward Rawlins], HERACLITUS RIDENS, July 26, 1681, at 2.

139. THE POWER AND PRIVILEGE OF JURIES ASSERTED, supra note 138, at 3-4. Hawles made an analogous argument, without developing the policy implications, in The English-Mans Right, where the juror hopes to avoid jury duty because "there sometimes happen [to be] nice cases, wherein it may be difficult to discharge ones conscience without incurring the displeasure of the Court, and thence trouble and damage may arise." HAWLES, supra note 62, at 2. 
therefore whoever takes away the Authority of Juries, takes away the Authority of the Judge...."140 When the question of jurors' personal knowledge arises, that sense of divided authority returns. Insisting that the juror should "proceed according to his evidence, Id est, his own knowledge," rather than "the external evidence or swearing of the witnesses," the author remarks that "Judges doe... determine the pertinency of Evidence" but are not permitted to determine "what credence [the jury] will give to it." ${ }^{141}$ The argument about power-sharing might simply be taken to repeat Vaughan's point about legitimacy-to undermine the jurors' authority is to undermine faith in the whole system-but the author seems to have wanted to claim for jurors an authority not shared with the judge, an authority that may trump that of the judge.

By the beginning of the following year, the trials of Colledge, Rouse, and Shaftesbury had also provoked a spate of less innovative arguments for nullification, which often took the same form as Hawles's The EnglishMans Right. These commentators typically imagined defendants harassed by malicious prosecutions, but then turned away from the attack on unjust laws to catalogue the other bases for jurors' refusal to be guided by the judge - bases such as the vicinage requirement and its attendant guarantee of a superior information base. This rhetorical structure is exemplified unusually crisply in a short pamphlet that also illustrates the disappearance, among the Whig polemicists, of any distinction between the petit and grand juries' duties. Probably published early in 1682, Ignoramus Vindicated, in a Dialogue Between Prejudice and Indifference ${ }^{142}$ begins with an explicit and by this time routine assertion of the jury's law-finding power. Invoking the slogan that "the Law arises out of, and is complicated with the Fact," the author, speaking through his mouthpiece "Indifference," defended the jury's prerogative to "refuse... to find Bills, though there be Positive Oaths before them," because the jurors "are Judges (in some respect) as of Law, as well of Fact." ${ }^{143}$ At first, "Indifference" says nothing about the jurors' personal knowledge of the defendant, but instead attacks politically motivated prosecutions:

[S]uppose a Man should be Indicted of High-Treason, for that he Traiterously, Maliciously moved by the Instigation of the Devil,

140. THE POWER AND PRIVILEGE OF JURIES ASSERTED, supra note 138, at 4.

141. Id. at 10 .

142. IGNORAMUS VINDICATED, IN A DIALOGUE BETWEEN PREJUdiCE AND INDIFFERENCE (London, William Inghall [1682]) [hereinafter IGNORAMUS VINDICATED]. Although the pamphlet is dated 1681, it refers to a court case heard in December 1681. See id. at 8 (describing "the Case of Samuel Wright and John Good [at] the very last Sessions"). Wright v. Good can be dated to "about December 1681." CARE, supra note 105, at 218. Under the "Old Style," see supra note 67 , the year ended on March 24; therefore, the pamphlet was probably published between January and March 1682.

143. IGNORAMUS VINDICATED, supra note 142, at 1-2. 
had, and kept an English Bible in his House: Now let an hundred and fifty people swear positively the Fact, viz. That he had such a Book in his Custody, would you ... charge the poor Man upon your Oaths, to answer for High Treason? ${ }^{144}$

"Prejudice," the author's foil, immediately challenges this characterization, and declares that "[t]here was no doubt or scruple in the late Cases, about matter of Law." 145 This would seem precisely the place to press the analogy and to challenge the legality of those prosecutions, but instead "Indifference" takes a new tack and affirms that "the Law supposes the Jury to know more of the Witnesses than the Court does." ${ }^{146}$ That answer, which the author elaborated at length, epitomizes not only a widely shared reluctance to accept the law-finding label, which is all the more striking because the author had just advocated it so directly, but also an extension to the grand jury of the petit jury's access to local information. That latter move, too, is typical of the pro-nullification pamphlets issued around this time: Vaughan's arguments were being extended wholesale to both juries.

The same pattern is evident in John Somers's The Security of EnglishMens Lives, ${ }^{147}$ which was published around the same time and went on to become one of the most popular defenses of the jury in England and America during the following century. The treatise opens with a rant against the "corrupt Ministers of State... who might commit the most odious of Murders in the form and course of Justice ... by corrupting of Judges, as dependant upon them for their Honour and great Revenue." 148 Cataloguing the many recent "Forgeries, Perjuries, Subornations, and Combinations of infamous Wretches...to defame Loyal, Innocent Protestants, and to shed their guiltless Blood in the Form and Course of

144. Id. at 2 .

145. Id. "[T]he late Cases" probably refers to the trials of Colledge, Rouse, and Shaftesbury; these media events provoked much more controversy than did the trials of Smith, Curtis, and Mallett in September 1680. In any case, the author could not have been referring to the trials of Harris and Care, since the juries in those cases did not return ignoramus verdicts.

146. Id. at 5.

147. [JOHN SOMERS], THE SECURITY OF ENGLISH-MENS LIVES (London, T. Mitchel [1682]). The first edition bears a publication date of 1681 ; however, the treatise presents a defense of the grand jury's ignoramus verdict at Shaftesbury's trial, on November 24, 1681. Given its lengthnearly 230 pages - the book probably took more than five weeks to complete and print. Therefore, under the "Old Style" system of dating, see supra note 67 , it was probably published between January and March 1682 . The book was published anonymously; for the attribution to Somers, see

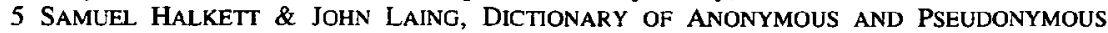
ENGLISH LITERATURE 214 (James Kennedy et al. eds., Haskell House 1971) (1926-1934). The imprint may be fictitious, since the English Short Title Catalogue lists no other publications issued under the imprint of "T. Mitchel." English Short Title Catalogue, at http://www.rlg.org/estc.html (last visited Feb. 26, 2002). In May, Somers's book was reissued in an edition that closely resembles this one but carries the date 1682 and gives the publisher as Benjamin Alsop, a prominent Whig bookseller. See Advertisement, IMPARTIAL PROTESTANT MERCURY, May 26, 1682, at 2 (advertising Alsop's edition).

148. SOMERS, supra note 147 , at 7 . 
Justice," Somers declared that "Grand Juries are our only Security." 149 They can be trusted, he argued, because they "know the Witnesses, and their Credit." 150 Though Somers did not derive this proposition specifically from Bushell's Case, he cited Vaughan's opinion near the outset of the treatise ${ }^{151}$ and drew implicitly on its arguments throughout.

Those arguments and assumptions reappear, once again, in an anonymous treatise also published early in 1682, A Guide to English Juries. ${ }^{152}$ The author devoted only a few pages specifically to Bushell's Case, ${ }^{153}$ but at other points drew heavily on Vaughan's opinion without attribution. Thus, for example, even before citing Bushell's Case, the author emphasized the variability of individual perception and remarked that " [n]o two Lawyers, nay, Judges reading or hearing the very same Case, but presently make different Inferences, Deductions, Collections, Conclusions, and Arguments, yea, the same Person at different times .... One can't see by another's Eyes." 154 Whereas Somers concentrated almost exclusively on the grand jury, the author of the Guide celebrated both the grand and petit juries' power to combat prosecutions that "menace[] the People with the worst of all Miseries, Law-oppression, Oppression under colour of Law." 155 The author thus noted that "the Grand Jury are not bound to find an Indictment, though [they] have Evidence, since they may know something of themselves to over-balance it," 156 and that "the [petit] Jury being so many Persons, and probably knowing something of the matter before, they may ... better observe, remember, and judge upon the whole matter, than any one or two, ... though called Judges." ${ }^{157}$ Even though Vaughan is not

149. Id. at 22-23. Because Somers leaned so heavily on the duties of the grand jury, he criticized Hawles's Grand Juryman's Oath for endorsing a lax standard of proof. Noting Hawles's statement that the jurors " "give in only a Verisimilar[y] or probable charge," Somers announced that "[n]othing can be more opposite to the Justice of our Laws, than such Opinions: All Laws in doubtful Cases direct a suspension of Judgment." SOMERS, supra note 147, at 129-30 (misquoting HAWLES, supra note 63, at 9).

150. SOMERS, supra note 147, at 153-54. As for the petit jury, Somers said they are "[d]wellers near about the place where the Crime is supposed to have been committed, to whom something of the Fact must probably be known." Id. at 11 .

151. See id. at 10.

152. "A PERSON OF Quality," A GuIDE TO ENGLish JuRIES (London, Thomas Cockerill 1682) [hereinafter A GUIDE TO ENGLISH JURIES]. The Guide was advertised as a new publication in January 1682. See Advertisement, IMPARTIAL PROTESTANT MERCURY, Jan. 13, 1681, at 2. Though the Guide's authorship is uncertain, an eighteenth-century inscription in the Huntington Library's copy of this pamphlet attributes it to John Somers. See "A PERSON OF QUALITY," A GUIDE TO JURIES (London, Thomas Cockerill 1699) (1682) (copy in Henry E. Huntington Library, San Marino, Cal., shelfmark 318,796) (bearing a handwritten notation, "Suppos'd to be writ by Mr Summers, afterwards Ld. Summers. 1 Sept: 1724. Ant Hammond").

153. See A GUIDE TO ENGLISH JURIES, supra note 152, at 37-38.

154. Id. at 31-32; see supra text accompanying note 42 .

155. Id. at 4.

156. Id. at 30 .

157. Id. at 14; see also id. at 27-28 (arguing that "the Jury is Neighbours of the Fact, of the Party, of the Witnesses, \&c. but the Judges strangers; and the Jury be more Persons, and the Judges fewer, \&c. The Jury also ... may go upon their own private knowledge"). 
credited, both of his main arguments concerning the basis of the jury's independence come into play here.

The Guide also illustrates another theme that was beginning to receive greater emphasis in the nullification literature: the suggestion that the jury's size lends legitimacy to its decisions. This claim had long been familiar in arguments concerning the advantages of the jury system, but around the time of the treason cases, a sense emerged that the jury's size might also lend legitimacy to the decision to nullify. This argument may also be found in a pamphlet published around the same time, entitled $A$ Discourse Touching the Addresses or Presentments to the King Against the Association. ${ }^{158}$ After reprinting the grand juror's oath and running through the vicinage requirement, the author paused to remark that the jurors, "being many, can see further into a matter, than one single person, and being upon their Oaths, must Act without favor or affection to either side: as perchance other persons which judg that the Verdict should be otherwise, may be some way or other prejudiced against the Person Charged." 159 The author did not draw what might seem the obvious corollary: that twelve people (or more, in the case of a grand jury) are also better qualified to find law than a single person, because any prejudice that colors a judge's view of the facts might also influence his perception of the law.

Indeed, this argument did not appear explicitly in the pamphlet literature, but it is implicit in Henry Care's argument in his 1682 treatise English Liberties, ${ }^{160}$ which looks closely at the relation between jury nullification and legitimacy. Care's paean to the English jury constitutes the book's final section, comprising some twenty-five pages. Care stressed the dangers of concentrating power in a single, unaccountable decisionmaker throughout this section:

158. A Discourse TOUChING the AdDRESSES OR PRESENTMENTS to the King AGainst THE Association (London, J. Hither 1682) [hereinafter A Discourse TOuCHING THE ADDRESSES]. The imprint may be fictitious, since the English Short Title Catalogue, supra note 147 , lists no other publications issued under this name. The pamphlet was probably published in February. See Advertisement, IMPARTIAL PROTESTANT MERCURY, Feb. 28, 1682, at 2 (advertising A Discourse Touching the Addresses as a new publication).

159. A DISCOURSE TOUCHING THE ADDRESSES, supra note 158, at 16.

160. CARE, supra note 105. Care's book was published by the same Benjamin Harris who was victimized in the seditious libel prosecutions, see supra text accompanying notes 67-69, and who had printed a leaflet on jury nullification, see supra note 113 and accompanying text. Care's book can be assigned a publication date of 1682 rather than 1680 , see supra note 62 , on the basis of a reference to a parliamentary petition read on June 2,1682. See CARE, supra note 105, at 116. Another signal of the publication date is Care's recommendation of "two Excellent, Leamed Treatises lately published, the one Intituled, A Guide to English Juries, \&c.... the other, The Security of English-mens Lives." Id. at 228. Both books were probably published carly in 1682 . See supra notes 147, 152. For further discussion of the bibliographical history of English Liberties, see Winthrop S. Hudson, William Penn's English Liberties: Tract for Several Times, 26 WM. \& MARY Q. (3d ser.) 578 (1969), which notes that there were "three initial editions ... but these appear to be separate issues of the same edition." Id. at $578 \mathrm{n}$. 1 . Though he misattributes the book to Penn, Hudson provides a useful description of the book's printing history. 
[L]ook abroad in France, Spain, Italy, or indeed (almost) where you will, and observe the miserable Condition of the Inhabitants, either intirely subjected to the Arbitrary Lusts of Tyrants, ... Or at best, you will behold them under such Laws as render their Lives, Liberties and Estates liable to be disposed of at the discretion of Strangers appointed their Judges, most times mercenary, and creatures of Prerogative. ${ }^{161}$

Care noted the risks of trusting entirely in the English judiciary, because "Judges are made by Prerogative[;] . . . Their places are so Honourable and Profitable, and their Tenure so Ticklish, viz., durante beneplacito, meerly during pleasure, that they lie under no small Temptations." 162 Care added that the accused "may challenge 35 in case of Treason, and 20 of them in Felony, without shewing any cause," ${ }^{163}$ and hinted that greater numbers are a better gauge of accuracy when he cited the unanimity requirement"every man of the Twelve must consent upon his Oath, or else 'tis all nothing" 164 - and concluded that "this method [is] more proper for bolting out the Truth ... than if the whole decision were left to the Examination of a Judge, or two or three, whose Interest, Passion, Haste, or Multiplicity of business may easily betray them into Error." 165 The "Priviledge of Tryal by Juries," Care concluded, is "amongst the choicest of our Fundamental Laws, which whosoever shall goe about openly to Suppress, or craftily to Undermine ... does Ipso Facto attacque the Government, and brings in an Arbitrary Power." 166

Care also argued for the parity of authority divided between judge and jury, arguing that the jurors were originally viewed as "Associates and Assistants to the Judges of the Court in a kind of Equality." 167 At the same time, Care sought to rein in the judge's power by insisting that "the Jury are the proper and only Judges" of the evidence, and that "the Judge has nothing to do to Intermeddle, he is bound by their Verdict." 168 Finally, Care also intensified a number of the arguments that were, by now, familiar among members of his camp. He called it a matter of "every dayes" practice for jurors to "apply[] matter of Fact and Law together," because in "most General Issues" such as trespass and breach of peace, the jurors

161. CARE, supra note 105, at 206.

162. Id. at 207.

163. Id. at 208. For further discussion of the judiciary's dependence on the Crown, see Lemmings, supra note 117.

164. CARE, supra note 105, at 208.

165. Id. at 208-09.

166. Id. at 209.

167. Id. at 211 .

168. Id. at 216 . 
routinely decided both matters. ${ }^{169}$ In his quotations from Bushell's Case, Care leaned heavily on both of Vaughan's arguments for crediting jurors' assessment of the evidence: He not only invoked the "personal knowledge" claim, ${ }^{170}$ but also quoted at length from Vaughan's remarks about the differences in individual perception and reasoning. ${ }^{171}$ In fact, Care devoted the last four pages of his book to a synopsis of Bushell's Case and quoted more of it than any of his contemporaries. ${ }^{172}$

If Care did not spell out the policy implications of his argument concerning the jury's role as a check on the judge, his comments on arbitrariness and prejudice strongly hinted that the jury is properly credited with a routine fact-finding power that rivals the power of the judge. That he did not argue this point directly is significant, but of all the nullification advocates, Care was the one who came closest to asserting the jury's superior competence in all aspects of trial administration-perhaps because of his own experiences. Like Hawles's pamphlet, Care's treatise would prove to be extremely durable: It went through four English editions in the next twenty years, and then was reprinted in North America. ${ }^{173}$

This eruption of pro-nullification literature encountered surprisingly little rebuttal, and the response it did engender consisted, for the most part, of diatribes like L'Estrange's, which simply criticized the ignoramus juries as shamelessly partisan without exploring the theory of nullification. One response that targeted the policy issues directly, however, was the 1682 pamphlet Billa Vera: Or, The Arraignment of Ignoramus, by the Tory journalist Laurence Womock. ${ }^{174}$ When addressing the grand jury's factfinding power, Womock asked, " $[\mathrm{H}] \mathrm{ow}$ is their Understanding to be directed?... [B]y ocular inspection and personal knowledge." 175 Such information, he observed, was simply unavailable to the grand jury:

169. Id. at 221; see also A GUIDE TO ENGLISH JURIES, supra note 152, at 21 (stating that the jurors "at their Election may take upon them knowledge of the Law, and determine both Fact and Law themselves.... [A]nd so is every daies Experience" ).

170. See CARE, supra note 105, at 225-26.

171. Id. at 224-28.

172. Id.

173. For the English editions, see Hudson, supra note 160, at 579. For the American editions, see infra note 178 and accompanying text.

174. [LAURENCE WOMOCK], Billa Vera: OR, THE ARRaignMENT OF IGNORAMUS (London, Robert Clavel 1682). The pamphlet was published anonymously; for the attribution to Womock, see 6 HALKETT \& LAING, supra note 147, at 294. It was published near the beginning of the year. See 1 ARBER, supra note 101, at 476 (listing an advertisement from February 1682).

175. WOMOCK, supra note 174 , at 8 . In elaborating this requirement, Womock described a view of character evidence that differs markedly from our modern standards:

Inquiry is to be made into [the defendant's] Manners, and the tenour of his Conversation; what Principles he has own'd, what Practices and Machinations he has been concern' $d$ in (for a wicked man is presumed to be no Changling, till he has given cleer, constant and lasting proofs of his amendment:) .... Id. at 9-10. 
[W] hat they alledge must not be upon Conjecture or a doubtful Hear-say, but upon their own certain knowledge; which, how men can pretend to in Matters of Fact, unless you'l make them Ubiquitaries and Omniscient; or the Matter of Fact be limited to such Circumstances of time and place, as they can positively say and swear they were individually privy to, cannot easily be imagined. And if they proceed upon an implicite Faith, that is no very credible practice, being derived from the Church of Rome, and deservedly condemn'd by all true Protestants. ${ }^{176}$

In attacking these claims on behalf of the jurors' personal knowledge, Womock was careful to insist that he spoke only of the grand jury. Anticipating a defense of the petit jury, he added, "[Y]ou tell me ... that these Juries are Judges; and . . I am very ready to acknowledge it; not only because it is the Opinion of Stephen Colledge,... but because it is the Judgment of my Lord Chief Justice North . . . But this is spoken of a Petty Jury." ${ }^{177}$ It is unclear why Womock refrained from disputing the petit jury's competence; perhaps he considered it irrelevant, since the nullification cases revolved entirely around grand juries. In taking such care to limit his remarks about "ubiquitaries" to the grand jury, however, Womock revealed how much authority the Whig interpretation of Vaughan's opinion had already acquired.

\section{THE EXPORT OF THE NULLIFICATION ARGUMENTS TO AMERICA}

Vaughan's use of the "personal knowledge" claim clearly proved useful for the advocates of nullification. As we have seen, many commentators simply copied Vaughan in drawing the connection between the institutional process originally used for selecting juries and the presumption that jurors knew more than judges about the facts of the case. During the eighteenth century, these arguments were taken up on the other side of the Atlantic, only to disappear in the years after the ratification of the Constitution. Indeed, from the time of the Revolutionary War, the rhetorical linkage between the vicinage requirement and the jury's independence seems to have lost its linchpin. Proponents of the requirement turned to claims about the jurors' familiarity with the defendant's character or to entirely separate justifications, such as neutrality and administrative efficiency. At the same time, advocates of jury independence began to focus on the need for a check on the judiciary and the importance of respecting jurors' personal judgments. Although it still appeared

176. Id. at 12 .

177. Id at 12-13. 
occasionally, the popular refrain of the 1680 s, which emphasized the jury's knowledge about the facts of the case, was slowly fading away.

Care's English Liberties was reprinted in Boston in 1721 by Benjamin Franklin's half-brother, ${ }^{178}$ and Franklin himself advertised copies for sale in his newspaper, the Pennsylvania Gazette, in $1734 .{ }^{179}$ The following year, during John Peter Zenger's famous libel trial, his lawyer, Andrew Hamilton, told the jurors that they had the power to reach a decision based on their presumptively superior knowledge about the case: "The law supposes you to be summoned out of the neighbourhood where the fact is alleged to be committed; and the reason of your being taken out of the neighbourhood is, because you are supposed to have the best knowledge of the fact that is to be tried." 180 The episode is reminiscent of the 1680 libel trials: Zenger, charged with libeling the much-hated Royal Governor of New York, was quickly acquitted by a jury who shared his political views. During the preceding thirty years, however, English courts had begun to require that jurors with personal knowledge about the case be sworn as witnesses, ${ }^{181}$ and shortly after Zenger's case, the rule was established in England that if a juror failed to follow that procedure, the defendant was entitled to a new trial. ${ }^{182}$ By the time Blackstone published his Commentaries in the late 1760 s, he could affirm that "the practice ... now universally obtains, that if a juror knows any thing of the matter in issue, he may be sworn as a witness, and give his evidence publicly in court." 183

Around the time of the American Revolution, there was another spate of reprints: Hawles's The English-Mans Right was printed in Boston in 1772, Somers's The Security of English-Mens Lives was printed in New York in 1773, and Care's treatise was printed in Providence in $1774 .^{184}$ Their renewed circulation may help account for the invocations of the

178. See 1 MoRris L. COHEN, BIBliography OF EARLy AMERICAN LAW 713-14 (1998) (noting the edition of Care's English Liberties published by "J[ames] Franklin").

179. See Advertisement, PA. GAZETTE, Aug. 29-Sept. 5, 1734, at 4.

180. R. v. Zenger, 17 STATE TRIALS, supra note 67, at 675, 703-04 (Aug. 4, 1735). Hamilton drew explicitly on Bushell's Case in his argument. See JAMES ALEXANDER, A BRIEF NARRATIVE OF THE CASE AND TRIAL OF JoHN PETER ZENGER 91 -93 (Stanley Nider Katz ed., Harvard Univ. Press 1963) ([1736]) (discussing and quoting from Vaughan's opinion). For discussion of other American cases during this period, see Renée B. Lettow, New Trial for Verdict Against Law: Judge-Jury Relations in Early Nineteenth-Century America, 71 NOTRE DAME L. REV. 505 (1996). Lettow notes that " [a]s conflict between the Crown and the colonists intensified [in the 1760s], so did assertions of jury power against the Crown's judges," with the result that "several eminent American lawyers and statesmen famously contended that juries had the right-not just the power-to decide the law as well as the facts in civil cases as well as criminal." Id. at 517 .

181. See John Marshall Mitnick, From Neighbor-Witness to Judge of Proofs: The Transformation of the English Civil Juror, 32 AM. J. LEGAL HIST. 201, 222 (1988) (citing decisions in King's Bench in 1702 and 1726 recommending this procedure).

182. See id. at 224 (citing Dormer v. Parkhurst, 95 Eng. Rep. 414 (K.B. 1738) (stating that if "any of the jury went on their own knowledge, without acquainting the Court therewith, it is such a misbehavior as is a foundation for granting a new trial")).

183. 3 WLLIAM BLACKSTONE, COMMENTARIES *375.

184. See COHEN, supra note 178 , at $138-40,714$. 
"personal knowledge" argument during the 1770s and 1780s. In a 1774 address concerning the rights of Englishmen, the Continental Congress celebrated the "great right... of trial by jury[,] [which] provides, that neither life, liberty nor property, can be taken from the possessor, [without the approval of] twelve of his unexceptionable countrymen and peers of his vicinage, who from that neighbourhood may reasonably be supposed to be acquainted with his character." ${ }^{185}$ In a notable substitution that would gain more support in the following years, this justification credits the jurors with some general acquaintance of the defendant, rather than with the more specifically relevant information about the case itself that earlier nullification advocates had emphasized.

Disagreement over a vicinage requirement for criminal defendants fueled an extended controversy during the constitutional ratification debates in the late 1780s. ${ }^{186}$ Although the Federalists generally opposed the requirement, the Anti-Federalists justified it by invoking such considerations as speed, ease of assembling evidence, and, in a few cases, the jury's superior knowledge base. Abraham Holmes of Massachusetts argued that the requirement would give the jury "an opportunity to form a judgment of the character of the person charged with the crime, and also to judge of the credibility of the witnesses." 187 Joseph M'Dowall of North Carolina and James Wilson of Pennsylvania echoed this view. ${ }^{188}$ The Virginia delegates canvassed the issue more extensively. Patrick Henry, citing the "immemorial practice of [our] British ancestors" under which "a number of hundredors were required on a jury," insisted on the criminal defendant's right to "an impartial jury of the vicinage, acquainted with his character and the circumstances of fact." ${ }^{189}$ George Mason defended the "impartial jury of the vicinage" as a "great palladium of national safety," because it guaranteed that the defendant would be judged by "his character and reputation." ${ }^{190}$ In response, Edmund Pendleton noted that a jury of the vicinage would not necessarily "be acquainted with the personal character of the person accused," ${ }^{191}$ since the requirement targeted the locality of the crime, not the defendant's neighborhood. Pendleton argued instead that

185. Address to the Inhabitants of Quebec (Oct. 26, 1774), in 1 JOURNALS OF THE CONTINENTAL CONGRESS, 1774-1789, at 105, 107 (Worthington Chauncey Ford ed., 1904).

186. For discussion of these debates, see Steven A. Engel, The Public's Vicinage Right: A Constitutional Argument, 75 N.Y.U. L. REV. 1658, 1680 (2000); and Drew L. Kershen, Vicinage, 29 OKLA. L. REV. 803, 816-44 (1976).

187. 2 The Debates in the Several State Conventions, on the adoption of the FEDERAL CONSTITUTION 110 (Jonathan Elliot ed., William S. Hein \& Co. 1996) (1891).

188. See 2 id. at $516 ; 4$ id. at 211.

189. 3 id. at 447 .

190. 3 id. at 528 .

191. 3 id. at 547 . 
they would "have some personal knowledge of the fact, and acquaintance with the witnesses, who will come from the neighborhood." 192

In spite of Pendleton's remarks, Mason's more diffuse claim about the jurors' knowledge was beginning to displace its predecessor-when any such claim was made at all. Indeed, Pendleton's very apt criticism helps to show that the emergent character-based argument was not only weaker than the original argument from personal knowledge but was even more implausible, since it addressed a concern that bears no direct relation to vicinage. That commentators were abandoning the former argument for the latter, then, may indicate the extent of their growing uneasiness with the former. The character-based argument was merely a way station on the road between the arguments of the $1680 \mathrm{~s}$ and the modern defense of jury independence.

Just as proponents of the vicinage requirement were turning to other justifications, proponents of jury independence were also beginning to look elsewhere. When collecting authorities on the subject in 1771, John Adams included a number of seventeenth-century decisions, including Bushell's Case, which indicated that "a Jury may give a Verdict on their own Knowledge ... without being sworn as Witnesses," ${ }^{193}$ but he ignored that argument a month later when he pillaged his fragmentary notes to produce a short essay on the jury's independence. Instead of discussing the jurors' personal knowledge, Adams drew implicitly on Vaughan's other argument and emphasized the "[a]bsurdity [of] suppos[ing] that the Law would oblige [the jurors] to find a Verdict... against their own Opinion, Judgment and Conscience." ${ }^{194}$ In a letter to the Abbé Arnoux in 1789, Thomas Jefferson cited Hawles's English-Mans Right, Somers's Security of English-Mens Lives, and the anonymous Guide to English Juries, ${ }^{195}$ but instead of referring to the jurors' knowledge, Jefferson justified their lawfinding powers by emphasizing the problem of judicial bias:

[P]ermanent judges ... are misled by favor, by relationship, by a spirit of party, by a devotion to the Executive or Legislative .... It is left therefore to the juries, if they think the permanent judges are under any biass whatever in any cause, to take upon themselves to judge the law as well as the fact. ${ }^{196}$

192. Id.

193. John Adams, Adams' Notes of Authorities (Jan. 1771), in I LEGAL PAPERS OF JOHN ADAMS 218, 221-22 (L. Kinvin Wroth \& Hiller B. Zobel eds., 1965).

194. John Adams, Adams' Diary Notes on the Rights of Juries (Feb. 12, 1771), in 1 LEGAL PAPERS OF JOHN ADAMS, supra note 193, at 228, 230.

195. Letter from Thomas Jefferson to the Abbé Arnoux (July 19, 1789), in 5 THE FouNDERS' ConstituTion 363, 363-64 (Philip B. Kurland \& Ralph Lerner eds., 1987).

196. Id. at 364 . 
Although these later eighteenth-century thinkers clearly had access to the "personal knowledge" argument that had been so energetically developed by the Whigs in the early 1680s, it apparently held little appeal for them.

Indeed, this argument would soon be expressly rejected by the judges who considered it. In an 1804 prosecution against newspaper publisher Harry Croswell for libeling Jefferson, ${ }^{197}$ Justice James Kent of the New York Supreme Court was confronted with the question whether the court could instruct the jury on the question of malicious intent or whether the jury could reach its own conclusions, even if intent was an inference of law. Kent surveyed a number of decisions, including Bushell's Case ${ }^{198}$ and while he praised Vaughan's "learned and profound argument," ${ }^{199}$ Kent did not discuss Vaughan's analysis but instead emphasized the jurors" obligation to "exercise their own judgments on the matter in issue, with discretion and integrity." ${ }^{200}$ Chief Justice Morgan Lewis argued that the judge could instruct the jury when the law inferred intent from certain actions, and after examining Bushell's Case more closely, he rejected Vaughan's suggestion that judges could not state the law in cases involving general verdicts. Lewis's analysis turns, in part, on his dissatisfaction with Vaughan's claims about the jurors' independent knowledge:

[Vaughan] ... assigns, as a reason why a jury is not justifiable for a false verdict, that the judge cannot know their evidence, for their verdict may be the result of their own knowledge of the fact, or such knowledge derived from each other. Surely, at this day, such doctrine is inadmissible, and destroys the authority of this case. ${ }^{201}$

Lewis offered no explanation for the "inadmissib[ility]" of Vaughan's argument; the developments of the previous century presumably rendered that conclusion self-evident.

By 1855, Chief Justice Lemuel Shaw of the Massachusetts Supreme Judicial Court could simply ignore the "independent knowledge" aspect of Vaughan's opinion when ruling on the permissibility of jury law-finding. In Commonwealth $v$. Anthes, ${ }^{202}$ which tested the legality of a statute giving the jury the right to find law, Shaw explained that Bushell's Case indicates that "[the jury] cannot be punished for finding against law," ${ }^{203}$ but he added that Vaughan's opinion "clearly implies that the judge, within his appropriate sphere, is ... to adjudge all questions of law, and direct the jury

197. People v. Croswell, 3 Johns. Cas. 337 (N.Y. Sup. Ct. 1804).

198. Id. at 369-70 (opinion of Kent, J.).

199. Id. at 370 .

200. Id at 377 .

201. Id. at 404-05 (opinion of Lewis, C.J.).

202. 71 Mass. 185 (1855).

203. Id. at 210. 
thereon." ${ }^{204}$ In considering the jury's law-finding power when rendering a general verdict, Shaw rejected Vaughan's conclusion that a juror "must find his verdict upon his own conviction and conscience." ${ }^{205}$ Shaw completely ignored the argument that the jury might have independent access to information about the case; instead, he focused on Vaughan's observation that "[a] man cannot... infer the thing to be resolved by another's understanding or reasoning." ${ }^{206}$ That proposition, Shaw argued, was irrelevant when "applied to the whole issue embraced in a general verdict," 207 because in such a case, the jury must accept the judge's instructions concerning legally specified inferences. That Shaw saw no reason even to mention the "personal knowledge" argument is notable. Lewis, writing in 1804, had found the argument "inadmissible"; a halfcentury later it apparently had so little force as not even to be worth rebutting. ${ }^{208}$

Shaw's account of Bushell's Case is the one that is preserved in Supreme Court case law. In the 1895 case of Sparf $v$. United States, ${ }^{209}$ the first Justice Harlan ruled that juries have the power, but not the right, to find law; in considering the relevance of Bushell's Case, he quoted directly from Justice Shaw's observations, which are quoted above. ${ }^{210}$ Sparf involved an appeal by two sailors who had been convicted of killing a shipmate. The appellants objected to an instruction by the trial judge that the jury could not take on a law-finding function by returning a verdict of manslaughter, but must find the accused either guilty or not guilty of murder. Harlan held that the jury was limited to finding the facts, and must follow the court's instructions concerning the law. Those who appeared to defend the contrary result, Harlan argued, had been concerned only with the limited set of cases involving "a general verdict, ... [which] disposes of the case at hand, both as to law and fact." ${ }^{211}$ After quoting from Somers's The Security of EnglishMens Lives to make this point, ${ }^{212}$ Harlan turned to Bushell's Case and Shaw's comments on it, and then underscored the limited scope of Vaughan's opinion: "[T]he leading thought in the opinion of Chief Justice Vaughan was that while the jury cannot answer as to the law, nor the court

204. Id.

205. Id. at 211.

206. Id. (quoting Bushell's Case, 124 Eng. Rep. 1006, 1012-13 (C.P. 1670)).

207. Id.

208. The only other contemporaneous American decision that refers to these issues in Bushell's Case also quotes Vaughan's remarks on individual perception and conviction, while similarly ignoring his comments on the jurors' independent knowledge. See Keener v. State, 18 Ga. 194, 235 (1855).

209. 156 U.S. 51 (1895).

210. Id. at $91-92$ (describing the "criticism... made by the Supreme Judicial Court of Massachusetts in the case of Anthes").

211. Id. at 90 .

212. Id. 
as to the fact, a general verdict, compounded of law and fact, of necessity determines both as to the case on trial." ${ }^{213}$ Justice Gray, in his dissent, undertook an intensive historical survey in order to argue that the jury had a more general right to find law, but although he quoted much more extensively from Bushell's Case, his account, too, ignored the "personal knowledge" argument in favor of Vaughan's comments on the uniqueness of each juror's individual perceptions. ${ }^{214}$ To read Vaughan's opinion through the lens of the leading American decision on jury nullification, then, would be to miss any acknowledgment of the argument that helped promote Bushell's Case during the first years of its public circulation.

\section{CONCLUSION}

Modern defenses of jury nullification routinely cite Vaughan's remarks concerning the subjectivity of individual perception and the importance of personal conviction. ${ }^{215}$ By contrast, references to his claims about the jurors' personal knowledge tend to appear only in historical discussions of the jury. ${ }^{216}$ That argument probably had no more plausibility when it first appeared than it did a hundred years later, when it was firmly rejected by Chief Justice Lewis. Rather, it seems to have served various functions for the Whigs that it could not support in the United States at the beginning of the nineteenth century.

Claiming to rely on fact rather than barefaced opposition to the law produces a veneer of respectability that undoubtedly helps explain the Whigs' fondness for this argument. The claims about jurors' personal knowledge, however, also bespeak a set of assumptions about the role of the jury and the legitimacy of its decisions. It has been observed that one of the main factors prompting juries to nullify involves a sense of kinship with the defendant. ${ }^{217}$ In such cases, even if the jurors are not personally acquainted with the defendant, their empathy may cause them to regard the

213. Id. at 93 .

214. See id. at 122 (Gray, J., dissenting).

215. See supra note 4.

216. See, e.g., Harold J. Berman \& Charles J. Reid, Jr., The Transformation of English Legal Science: From Hale to Blackstone, 45 EMORY L.J. 437, 469 n.60 (1996) (quoting Vaughan's comments concerning personal knowledge, as quoted in DUNCOMBE, TRYALS, supra note 9, at 444); Stephan Landsman, A Brief Survey of the Adversary System, 44 OHIO ST. L.J. 713, 722 (1983) (" "The] court held, in Bushell's Case, that jurors were free to reject the evidence presented in court and base their decision on private knowledge." (footnotes omitted)); Barbara J. Shapiro, "To a Moral Certainty": Theories of Knowledge and Anglo-American Juries 1600-1850, 38 HASTINGS L.J. 153, 164 n.27 (1986) ("Vaughan ... noted that juries might have personal knowledge of the case unknown to the judge ....").

217. See John Clark, The Social Psychology of Jury Nullification, 24 LAW \& PSYCHOL. REV. $39,50(2000)$ (noting that " "[a]n individual views others as belonging to [his or her] own group (the in-group) or to another group (the out-group)," and that "a defendant who is perceived to possess ... in-group standing ... stands a greater chance of acquittal" (citation omitted)). 
attack as "personal." Thus, the Whigs' claims about personal knowledge may capture a sense that the jurors had a privileged understanding of the defendant's plight, even though the seventeen members of Colledge's London grand jury were most unlikely to know anything about the facts of his case.

The "personal knowledge" claim also served a rhetorical purpose. Those who wanted to encourage nullification sought to ground the jury's conduct in an authority commensurate with that of the judge. Specifying an independent source of information allowed these advocates to find a means of counterbalancing the witnesses who testified under oath on behalf of the government. By placing the jurors on the same level as the judge, this claim also validated the assertion that juries may find law as well as fact. To justify nullification by invoking a superior knowledge base is to combat the arbitrary administration of justice with a weapon that suits the law's internal account of legitimate decisionmaking. ${ }^{218}$ The imputation that the seditious libel and treason prosecutions were illegitimate pervades the pamphlet literature, from the hypothetical examples in The English-Mans Right and Ignoramus Vindicated, to Harris's complaint about judges who conceal the legal basis of their rulings, to Care's remarks about biased judges who must be checked by a large and impartial jury. Although it might be sufficient to say that resistance is always an appropriate response to the abuse of power, the further suggestion that juries were hewing to principle in the face of an arbitrary judiciary seems to have been irresistible. As we have seen, this argument emerged as the nullification debate continued, and was reflected in Jefferson's later defense of jury independence. ${ }^{219}$

Neither of these purposes would have been served by emphasizing the jurors' right to judge according to their own perceptions. This argument, readily cast in terms of idiosyncrasy and eccentricity, would not have communicated the sense of personal conviction and empathy implicit in the "personal knowledge" argument, and it would have lacked the rhetorical weight to compete with the judge's authority. Further, in emphasizing an entirely subjective standard, such claims might have provoked more of the ridicule that the Tories directed at Colledge's London jury. ${ }^{220}$

218. Womock responded to the argument that the jury was entitled to the same degree of authority as the judge: "If these Jurors will put themselves upon the Bench, with Judges, they must be content to take the like fate with them, when they are observed to do amiss." WOMOCK, supra note 174 , at 25 . Womock thus countered the policy rationale for privileging jurors with a policy rationale of his own, noting that unrestrained power for any of the participants in the trial judgment raises the threat of arbitrary or prejudiced behavior, with the result that all must be equally cligible for censure.

219. See, e.g., supra text accompanying note 196.

220. See supra note 124 and accompanying text. 
Whereas the victims of the Stuarts' libel and treason prosecutions belonged to a cohesive faction willing to embrace an implausible justification so long as it suited their political needs, the Anti-Federalists of the 1780s lacked the incentive to ignore the reality about the juries' knowledge of the cases before them. The Restoration Whigs developed their nullification arguments as a means of self-defense in the face of a direct threat, but the later eighteenth-century arguments advanced by both Federalists and Anti-Federalists were more hypothetical in nature. Rather than attempting to defend their actions, these commentators sought persuasive justifications for the laws they were crafting, and to some extent they were also weighing policy arguments to determine which rules to adopt. In consequence, they often invoked the "personal knowledge" argument half-heartedly or turned instead to the jurors' obligation to find according to their conscience. These recyclings of the Restoration Whigs' arguments, however, help to remind us of the process by which Vaughan's earlier exponents put these twin justifications into circulation at a time when they could be taken up, multiplied, and refined, so that the latter explanation was ultimately preserved when the first one finally lost its power.

As noted above, one of the most remarkable aspects of the debate over Bushell's Case involves the Tories' willingness to concede that petit jurors have a right to find law. That concession suggests that despite Vaughan's own views about nullification, his decision quickly took on a meaning that he would have rejected. Although the holding in Bushell's Case marks an important moment in the history of jury nullification, the case's importance also depends in part on the debates it provoked. The full significance of a legal decision is rarely discernible from the outset; rather, decisions acquire meaning as they are used by other courts and commentators. Thus, a historical understanding of the nature of jury nullification in the seventeenth and eighteenth centuries must attend not only to the language of Vaughan's decision, but also to the debates that followed. Although a consideration of Bushell's Case, in isolation, would find little scope for any law-finding right on the jury's part, such a right finds a much stronger foundation in the legal and rhetorical battles that Vaughan's opinion engendered. 
***

Imaged with the Permission of Yale Law Journal 